\title{
U.S. Pellet Industry Overview
}

\author{
Patrick Lamers
}

\author{
January 2017
}

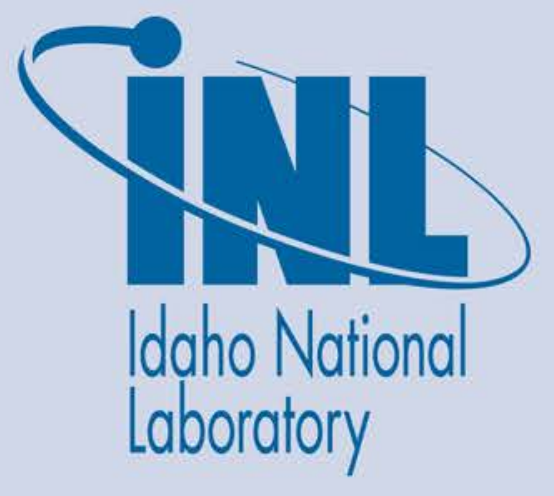

The INL is a U.S. Department of Energy National Laboratory operated by Battelle Energy Alliance 
INL/EXT-17-41028

\title{
U.S. Pellet Industry Overview
}

\author{
Patrick Lamers
}

January 2017

\section{Idaho National Laboratory \\ Idaho Falls, Idaho 83415}

http://www.inl.gov

\author{
Prepared for the \\ U.S. Department of Energy \\ Assistant Secretary for __, OR Office of \\ Under DOE Idaho Operations Office \\ Contract DE-AC07-05ID14517
}




\begin{tabular}{|c|c|}
\hline $\begin{array}{l}\text { ID\#: } \\
\text { 1.2.1.5.ML.1 } \\
\text { Type: Regular } \\
\text { (DL): Regular } \\
\text { WBS \#: } 1.2 .1 .5\end{array}$ & $\begin{array}{l}\text { Completion Date: 12/31/2016 } \\
\text { Scheduled Completion: 12/31/2016 }\end{array}$ \\
\hline Milestone Title: & U.S. Pellet Industry Overview \\
\hline Authors: & Patrick Lamers \\
\hline $\begin{array}{l}\text { Project Name: } \\
\text { Project Leader: }\end{array}$ & $\begin{array}{l}\text { Sustainable Feedstock Production-Logistics Interface } \\
\text { Patrick Lamers }\end{array}$ \\
\hline Key Words: & Pellets, Wood Products, Forestry \\
\hline
\end{tabular}

INL/EXT-17-41028 


\section{TABLE OF CONTENTS}

1. Regulatory framework, market drivers and barriers............................................................... 1

1.1. Drivers for domestic pellet consumption and production ................................................... 1

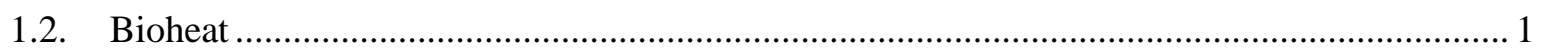

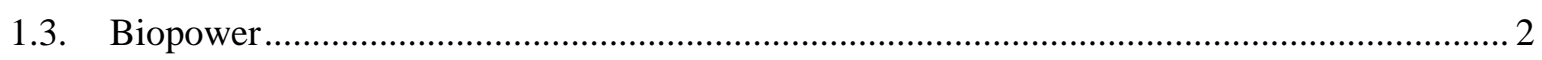

1.4. Biofuels and Biomass Crop Assistance Program (BCAP) ................................................ 2

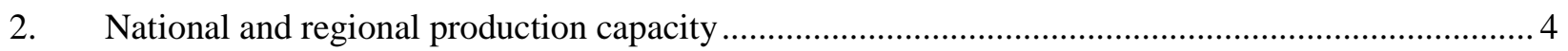

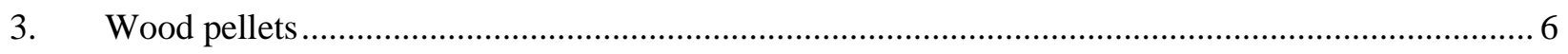

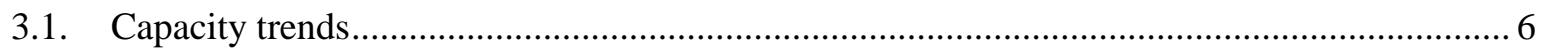

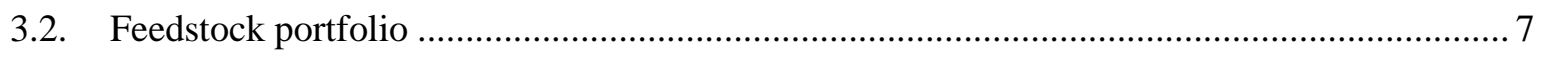

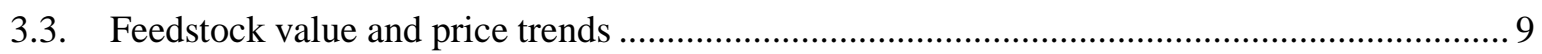

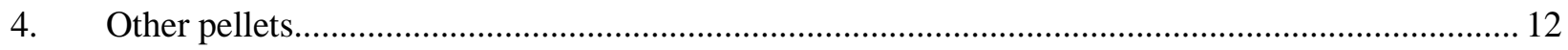

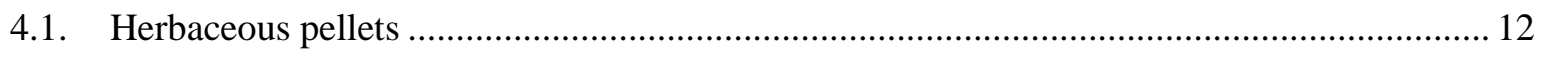

4.2. Feedstock portfolio, value and willingness-to-pay …................................................... 13

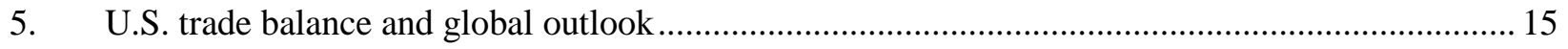

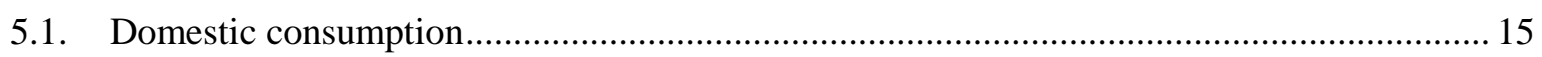

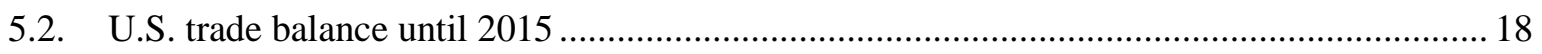

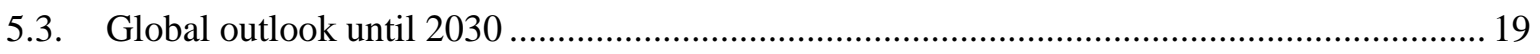

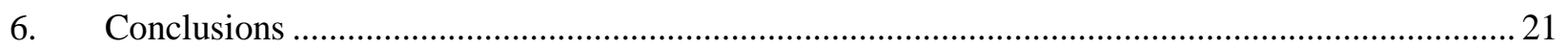

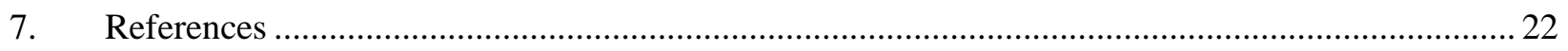

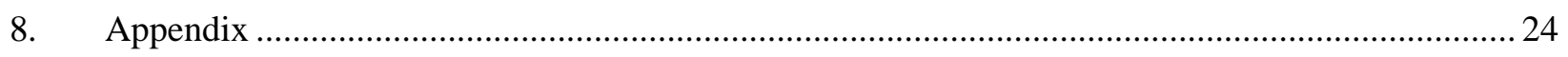




\section{ABBREVIATIONS AND ACRONYMS}

$\begin{array}{ll}\text { AFEX } & \text { Ammonia Fiber Expansion } \\ \text { ARA } & \text { Amsterdam, Rotterdam, Antwerp } \\ \text { BETO } & \text { U.S. Department of Energy's Bioenergy Technologies Office } \\ \text { C\&D } & \text { Construction and Demolition } \\ \text { CIF } & \text { Cost, Insurance, Freight } \\ \text { dbh } & \text { diameter breast height } \\ \text { DDGS } & \text { Distiller's Dried Grains with Solubles } \\ \text { DOE } & \text { U.S. Department of Energy } \\ \text { EIA } & \text { U.S. Energy Information Administration } \\ \text { EN } & \text { European Norm } \\ \text { EU } & \text { European Union } \\ \text { FAME } & \text { Fatty Acid Methyl Ester } \\ \text { FAS } & \text { Free-Alongside-Ship } \\ \text { FDA } & \text { U.S. Food and Drug Administration } \\ \text { FOB } & \text { Free-On-Board } \\ \text { FY } & \text { Fiscal Year } \\ \text { ISO } & \text { International Standardization Organization } \\ \text { MYPP } & \text { Multi-Year-Program-Plan } \\ \text { OSB } & \text { Oriented Strand Board } \\ \text { USDA } & \text { U.S. Department of Agriculture } \\ \text { wt\% } & \text { Weight percent } \\ \text { WTP } & \text { Willingness-To-Pay } \\ & \end{array}$




\section{REGULATORY FRAMEWORK, MARKET DRIVERS AND BARRIERS}

This section provides an overview of federal policies that may have had an impact on the production, consumption or trade of U.S. pellets.

\subsection{Drivers for domestic pellet consumption and production}

\section{Consumption}

The main drivers for wood pellet consumption in the U.S. have been regional price competitiveness with residential heating oil and propane as well as replacements of fuelwood burners with respect to comfort and automatic feed-in. There are some incentives for bioheat (see Section 1.2) targeted at the residential and commercial building sector. Industrial use of wood pellets in heat and power is not incentivized. In fact, industrial consumption of wood pellets for heat and power production is marginal at best. The primary use of woody biomass is limited to direct by-product (residue) use in the forest products sector, e.g., pulp and paper. The Renewable Portfolio Standards (RPS) mandate the production of renewable electricity, including biopower, but wood pellets are usually not used in biopower facilities due to price. The Clean Power Plan (CPP) could increase domestic wood pellet consumption in the electricity sector, but its implementation is uncertain and its market impact unknown and potentially limited.

\section{Production}

U.S. wood pellet production started in the Northwest and Northeast, where small-scale production based on sawmill residues supplied regional residential heating markets. These markets grew but were ultimately limited by the expansion of the natural gas network and a limited price competitiveness of wood pellets. U.S. production grew exponentially over the past years due to demand from overseas markets. The expansion took place almost exclusively in the Southeast (with some production increases along the East Coast) due to strategic factors including proximity to EU markets, traditional wood basket including availability of biomass resources, labor, infrastructure, and know-how.

\subsection{Bioheat}

\section{New Source Performance Standards (NSPS) by the EPA}

In March 2015, the Environmental Protection Agency (EPA) issued New Source Performance Standards (NSPS) for new residential wood heaters, including pellet stoves.

\section{Biomass Stove Tax Credit}

The Biomass Stove Tax Credit is a federal incentive that gives a \$300 tax credit for purchasing a fuelwood or wood pellet stove with a minimum 75\% efficiency rating until December 31, 2016 (details of the law at: https://www.law.cornell.edu/uscode/text/26/25C).

\section{Rebates through regional Woodstove Changeout Programs}

Woodstove changeout programs are aimed at providing consumers with incentives to remove old, inefficient wood stoves or wood heating appliances, and replace them with clean, efficient new heating appliances. Incentives mainly include rebates for new stoves. 14 U.S. states currently provide such incentives. Details per state/region at: http://www.hpba.org/government-affairs/woodstove-changeoutprogram/current-changeout-programs. 


\subsection{Biopower}

On federal level, there is significant uncertainty as to the potential implementation of the CPP, proposed by the U.S. EPA. In February 2016, the Supreme Court stayed implementation of the CPP Plan pending judicial review. Also, the exact role biomass can play in meeting CPP requirements is still unclear. Independent of the federal implementation of the CPP, individual states may push for the reduction of greenhouse gas emissions, e.g., via a phase-out of coal. In Colorado, for instance, the electricity company Xcel Energy is planning to pursue a phase-out plan for coal independent of the federal implementation of the CPP. Also, most states have renewable portfolio standards or goals in place (Figure 1). These standards require that utility companies generate a certain amount of energy from renewable resources by a certain date. For example, a certain percentage of the utility's electric power sales must be generated from renewable energy sources. Biomass is however only one from of renewable energy eligible to meet these targets - in addition to wind, solar, hydropower, etc.

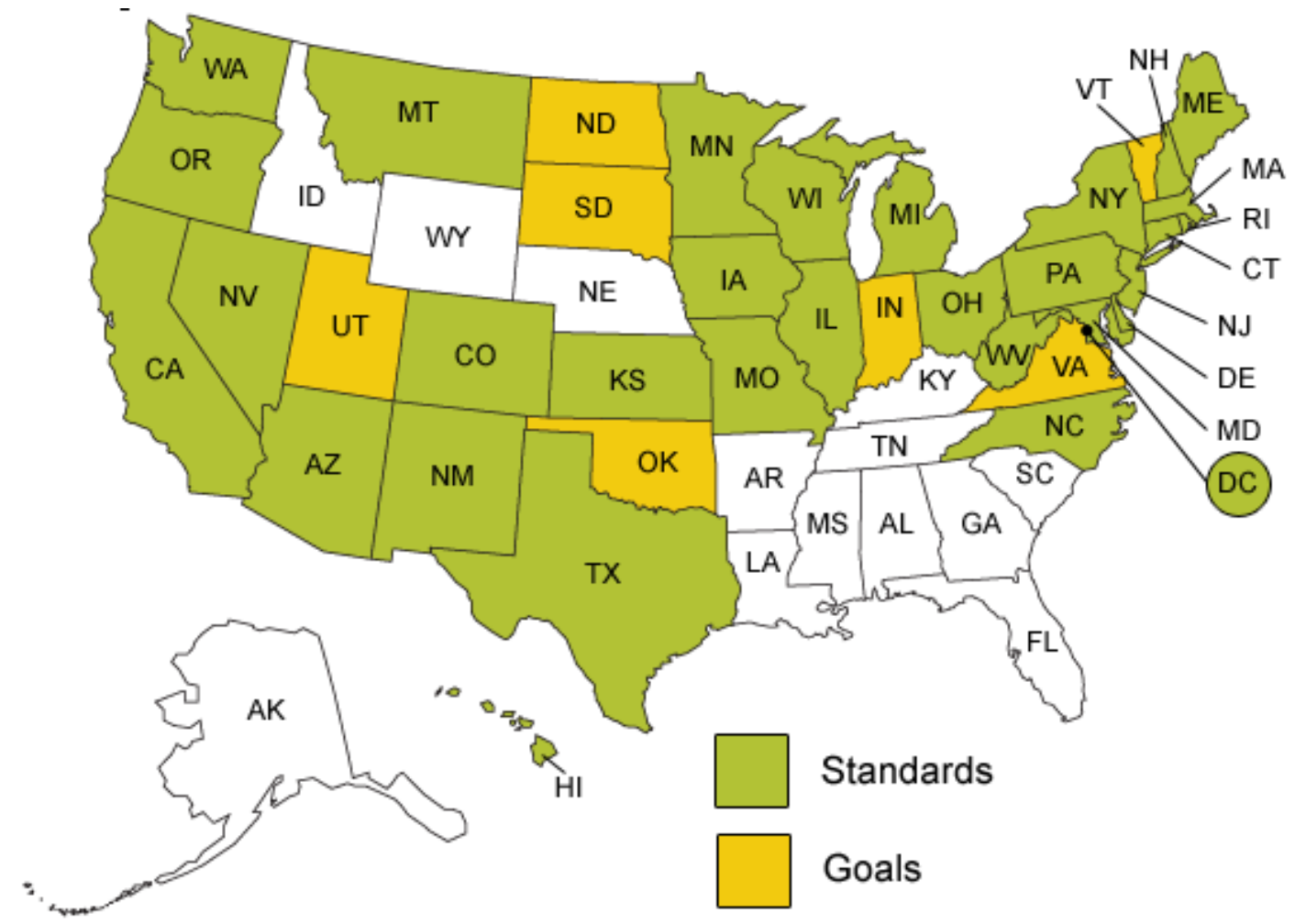

Figure 1. U.S. states with renewable portfolio standards (mandatory) or goals (voluntary) - by January 2012 (http://www.eia.gov/todayinenergy/detail.cfm?id=4850).

\subsection{Biofuels and Biomass Crop Assistance Program (BCAP)}

Wood pellets have the potential to become a key input feedstock to biorefineries producing advanced biofuels. At this point however, the nascent industry has not yet triggered a vast expansion of wood pellet production.

While tax credits for starch ethanol and FAME (biodiesel) have been terminated (ethanol at the end of 2011, biodiesel at the end of 2014), the biofuel industry is still able to benefit from indirect financing via agricultural and forest feedstock support programs, predominantly the Biomass Crop Assistance Program 
(BCAP). It was created as part of the 2008 Farm Bill (The Food, Conservation, and Energy Act of 2008) to reduce U.S. reliance on foreign oil, improve domestic energy security, reduce carbon pollution, and spur rural economic development and job creation. ${ }^{\text {a }}$ It is now in its $4^{\text {th }}$ Amendment and supported by the 2014 Farm Bill. ${ }^{\mathrm{b}}$

BCAP was initially put in place to help address bioenergy's “chicken-and-egg” challenge of establishing commercial-scale biomass conversion facilities and sufficient feedstock supply systems simultaneously:

- Conversion facilities must have reliable, large-scale feedstock supplies to operate, but there are no existing markets for accessing these materials

- Biomass feedstock producers do not have sufficient incentive to produce these materials because of the lack of existing markets to purchase their biomass.

The BCAP provides two categories of financial assistance to owners and operators of agricultural and non-industrial private forest land who wish to establish, produce, and deliver biomass feedstocks:

First, establishment and annual payments may be available to certain producers who enter into contracts with the Commodity Credit Corporation (CCC) to produce eligible biomass crops on contract acres within BCAP project areas. In 2006, 20\% of the U.S. corn harvest was used for ethanol production. The total agricultural subsidies through the CCC (under BCAP) for corn that year totaled $\$ 8.8$ billion. ${ }^{\mathrm{C}}$ Thus, an estimated \$1.8 billion went to subsidize corn destined for ethanol production.

Second, matching payments may be available to eligible material owners (EMO) for the sale and delivery of eligible material to qualified biomass conversion facilities (QBCF). Qualified biomass conversion facilities produce research, heat, power, biobased products, or advanced biofuels from biomass feedstocks. These payments are available to EMOs at the rate of $\$ 1$ for each $\$ 1$ per dry ton paid by QBCF to EMOs, limited to a maximum of $\$ 20$ per dry ton and limited to a 2-year payment duration. All payment rates used in sales transactions between EMOs and QBCFs must reflect fair market values for the various types and varieties of eligible material biomass.

QBCF operations must register and be accepted as an eligible facility under BCAP. In FY16 (10/1509/16), most accepted facilities were based on forest residues (followed by agricultural/orchard residues), including the following wood pellet plants ${ }^{\mathrm{d}}$ :

- Confluence Energy, CO (at locations in Walden and Kremmling), sourcing primarily dead (mountain pine beetle kill) trees: combined capacity 210,000 tons

- Forest Energy Corporation, AZ (Show Low location): 62,000 tons capacity

- Zilka Biomass, AL (Selma plant): 300,000 tons capacity

\footnotetext{
${ }^{\mathrm{a}}$ http://www.fsa.usda.gov/Internet/FSA_File/bcapoctrules.pdf [October 8, 2016].

${ }^{\mathrm{b}}$ http://www.fsa.usda.gov/Assets/USDA-FSA-Public/usdafiles/Energy/1bcap-a4.pdf [October 17, 2016]

${ }^{\mathrm{c}}$ http://www.usda.gov/oce/newsroom/archives/testimony/2007files/Collins_011007.pdf [October 17, 2016]

${ }^{\mathrm{d}}$ http://www.fsa.usda.gov/Assets/USDA-FSA-Public/usdafiles/Energy/bcap_facility_listing_FY2016.pdf [October 17, 2016].

Project information in accordance with DOE Contract No. DE-AC07-05ID1451 


\section{NATIONAL AND REGIONAL PRODUCTION CAPACITY}

The Biomass Magazine provides company information on Canadian and U.S. pellet mill plants (BiomassMagazine 2016). The data was cross-checked with industry information gathered the U.S. International Pellet Association (USIPA) Conference in Miami, FL. For example, Biomass Magazine (2016) states American Biocarbon to operate a 200,000 ton facility using sugarcane field residues in Louisiana. At present however, the facility is only producing at pilot scale $(10,000$ ton capacity) with plans to build a larger plant onsite later on (Cohn 2016). Therefore, it is expected that capacity numbers listed by Biomass Magazine (2016) are rather optimistic and should be interpreted with caution.

By the end of 2016, the industry has reached an operational production capacity (nameplate) of over 14 million tons with an additional 2.5 million tons under construction. Wood pellets represent the majority of this volume at 13.9 million tons of the nameplate capacity in operation. A complete list of all pelleting operations across the U.S. is provided in the Appendix.

Table 1. US pelleting capacity by feedstock.

\begin{tabular}{|c|c|c|}
\hline Feedstock & Capacity (tons) & Subtotal \\
\hline Agricultural residues & 10,300 & \\
\hline Biomass Crops & 40,000 & \\
\hline Crop Residue & 10,000 & \\
\hline Subtotal herbaceous biomass & & 60,300 \\
\hline Hardwood & $1,831,950$ & \multirow[b]{4}{*}{$13,884,205$} \\
\hline Softwood & $5,035,600$ & \\
\hline Hardwood and Softwood & $7,016,655$ & \\
\hline Subtotal woody biomass & & \\
\hline Paper Waste & 170,000 & \multirow[b]{3}{*}{ 481,015 } \\
\hline Unknown & 311,015 & \\
\hline Subtotal other & & \\
\hline TOTAL operational & $14,425,520$ & \\
\hline Under construction & $2,562,250$ & \\
\hline Planned & $4,722,800$ & \\
\hline
\end{tabular}

The geographic distribution of U.S. pellet plants coincides with regional resource availability (Figure 2).

Small- and medium-scale plants, producing largely wood pellets for the domestic heating market are concentrated in the Northeast and Northwest. Large-scale, export-oriented wood pellet producers are located in the Southeast. The highest concentration of crop residues in the Midwest has little to no pelleting capacity (Figure 3). 


\section{Idaho National Laboratory}

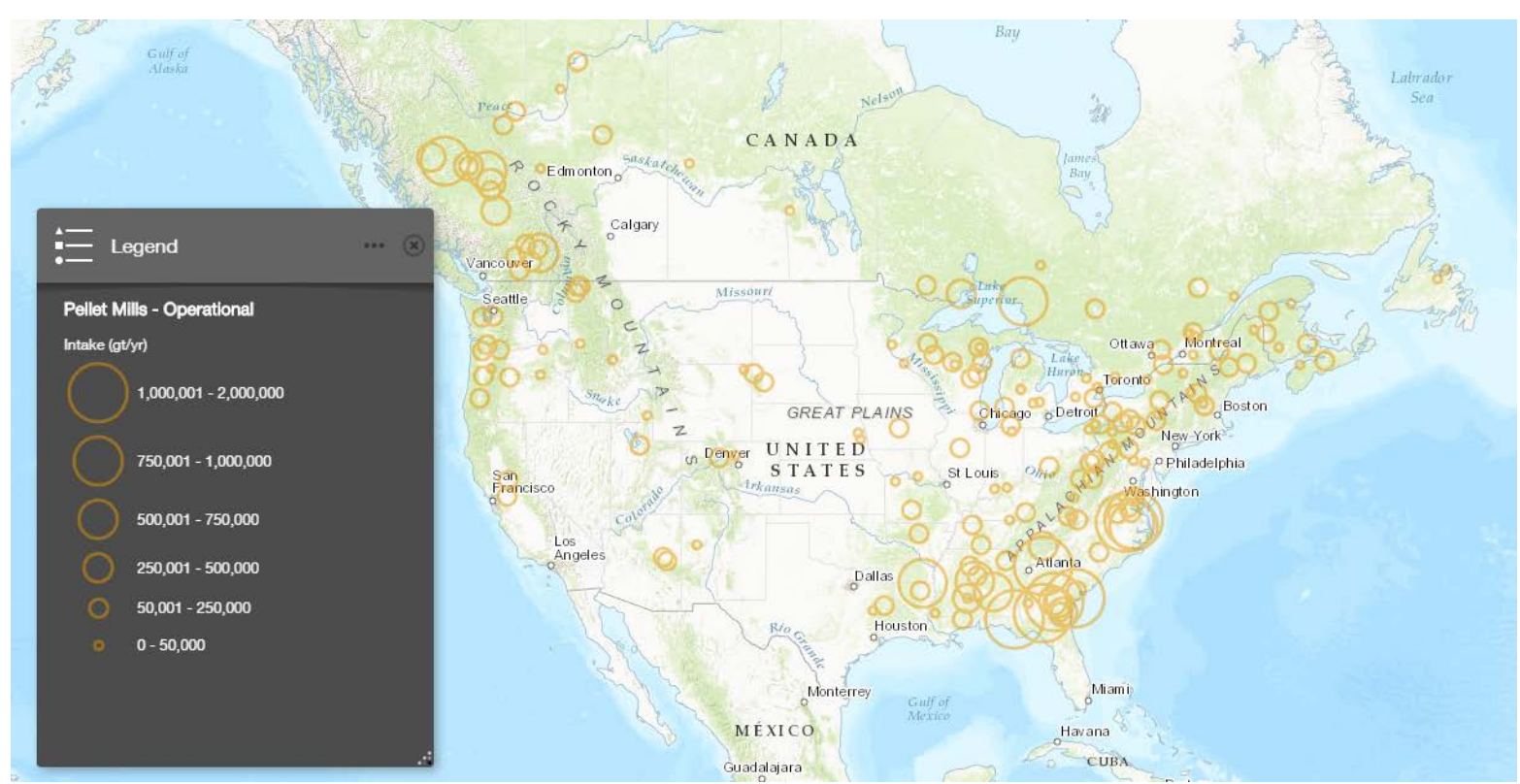

Figure 2. North American pellet mill locations (Source: Wood2Energy.org).

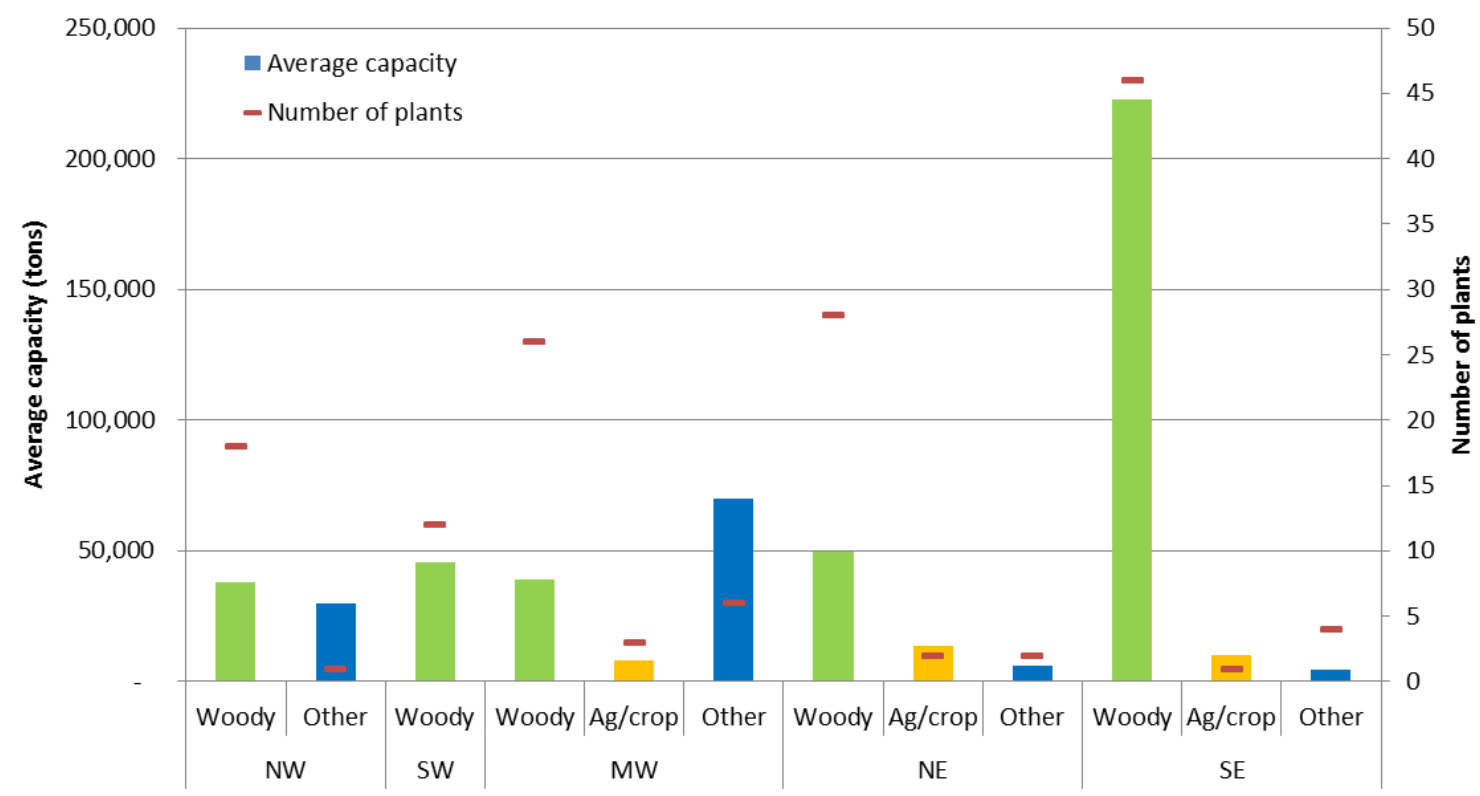

Figure 3. Regional distribution of feedstock choice, average plant size, and number of facilities. Note: The individual states included per region are presented in Table 8 in the Appendix. 


\section{WOOD PELLETS}

\subsection{Capacity trends}

Wood pellet production has seen steady growth since 2004, with an exponential increase across the U.S. South (Figure 4). In the southern U.S., 119 mills consuming pulpwood and residual chip fiber were operating by 2015; the same number as in 2000 (Forest2Market 2015). However, there had been an internal shift in the sector from pulp and paper to wood pellet production. 16 new wood pellet facilities were built in the U.S. South since 2005. Between 1995-2015, 14 pulp and paper mills permanently closed across the southern U.S., (Forest2Market 2015). The panelboard and oriented-strand-board (OSB) sector had both openings and closings across the same period with a net loss of three panelboard and a net growth of four OSB facilities (Forest2Market 2015).

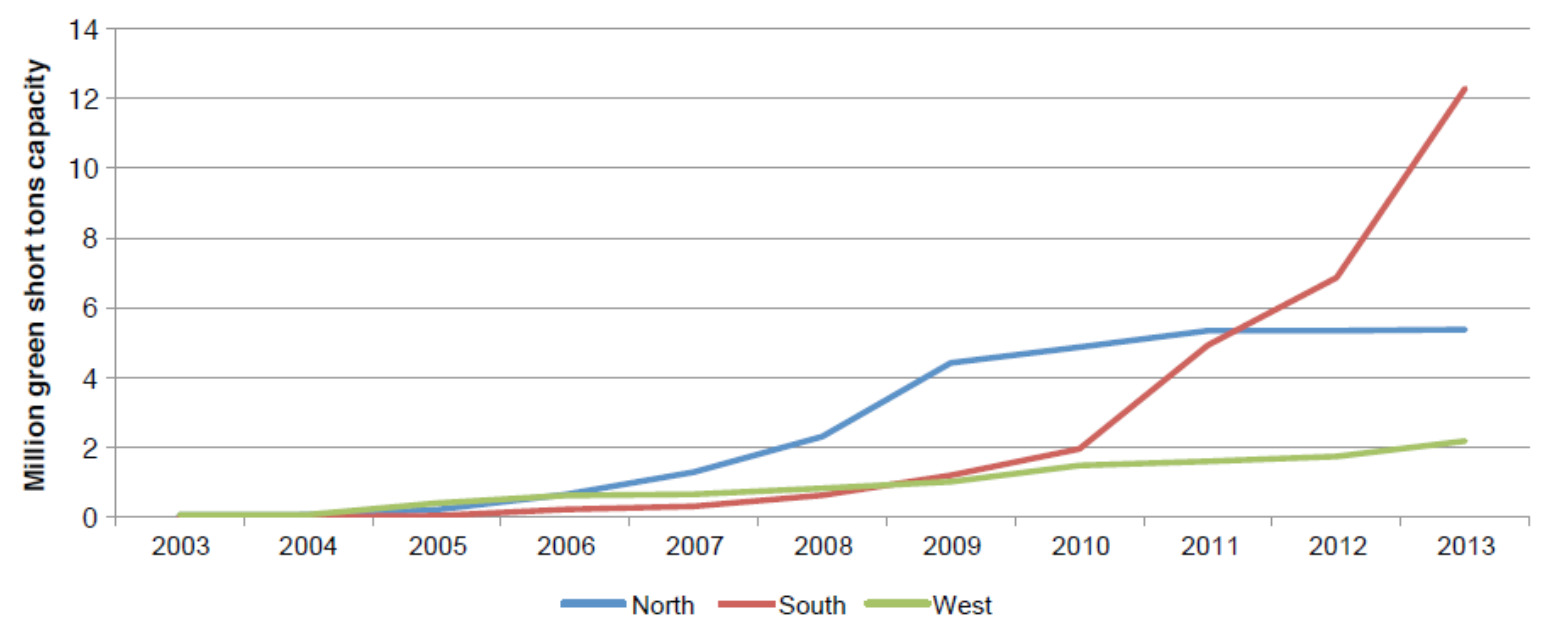

Figure 4. Growth in pellet production capacity by U.S. region from 2003 through 2013 (Forisk Consulting in Abt et al. 2014)

There are 14 wood pellet plant operations above 300,000 tons annual capacity; all located within the southeastern U.S. (Table 2). The main operations and market actors include:

- Enviva: most plants (seven) with a total capacity of 3 million tons

- Drax: a combined capacity of 996,000 tons with its Amite BioEnergy and Morehouse BioEnergy plants

- Georgia Biomass: largest single plant in the U.S. with 825,000 tons capacity, owned and operated by RWE Innogy

- German Pellets used to be a significant market actor, but filed for insolvency of two U.S. subsidiaries in 2016, reducing its overall production share

Plant operation times are usually in the range of 7,000 hours per year (Wild 2016), reducing actual annual production to about $80 \%$ of the nameplate capacity. 
Table 2. U.S. wood pellet plants above 300,000 tons annual capacity (Biomass-Magazine 2016).

\begin{tabular}{|l|l|l|r|}
\hline Plant & State & Feedstock & Capacity (tons) \\
\hline Georgia Biomass (RWE) & GA & Softwood & 825,000 \\
\hline Hazlehurst Wood Pellets & GA & Softwood & 700,000 \\
\hline Enviva Pellets Cottondale & FL & Softwood & 660,000 \\
\hline Highland Pellets* & AK & Softwood & 600,000 \\
\hline German Pellets Louisiana & LA & Softwood & 578,000 \\
\hline German Pellets Texas & TX & Hardwood and Softwood & 551,155 \\
\hline Enviva Pellets Northampton & NC & Hardwood and Softwood & 550,000 \\
\hline Enviva Pellets Southampton & VA & Hardwood and Softwood & 550,000 \\
\hline Enviva Pellets Hamlet & NC & Woody Biomass & 550,000 \\
\hline Blue Sky Biomass Georgia & GA & Woody Biomass & 540,000 \\
\hline Amite BioEnergy (Drax) & MS & Hardwood and Softwood & 500,000 \\
\hline Morehouse BioEnergy (Drax) & GA & Woody Biomass & 496,000 \\
\hline Enviva Pellets Ahoskie & NC & Hardwood and Softwood & 449,000 \\
\hline Westervelt Renewable Energy & AL & Softwood & 309,000 \\
\hline Zilkha Biomass - Selma & AL & Hardwood and Softwood & 303,000 \\
\hline
\end{tabular}

*Note: Highland Pellets, Pine Bluff, AK, is currently still undergoing commissioning but is expected to start operation by the end of $2016^{e}$.

\subsection{Feedstock portfolio}

Feedstock used in wood pellet mills ranges from primary (harvesting) to secondary (processing) residue streams and stemwood. Typical feedstock includes residual chip fiber and pulpwood, i.e., the same feedstock as panelboard, OSB or pulp and paper mills.

Small-size ( $<150,000$ tons) pellet mills derive most of their feedstock from sawmill operations in the form of dry sawdust and residue chips. As such they require proximity and logistical connection to these facilities. Also, since they rely on a residue stream of another industry, they are limited in output capacity and scale-up.

Medium- (150,000-300,000 tons) and large-size (>300,000 tonnes) pellet mills also use residue streams from the wood products sector, but this share declines with increasing pellet plant capacity. Larger plants derive an increasing fraction of their feedstock from silviculture operations directly, e.g., thinnings, salvage wood, and pulpwood.

Figure 5 shows the increase in silviculture by-products in total feedstock portfolios across the southern U.S. with the deployment of large-scale pelleting operations.

\footnotetext{
e http://www.biomassmagazine.com/articles/14001/highland-pellets-commissions-arkansas-pellet-plant [December 8, 2016].
} 


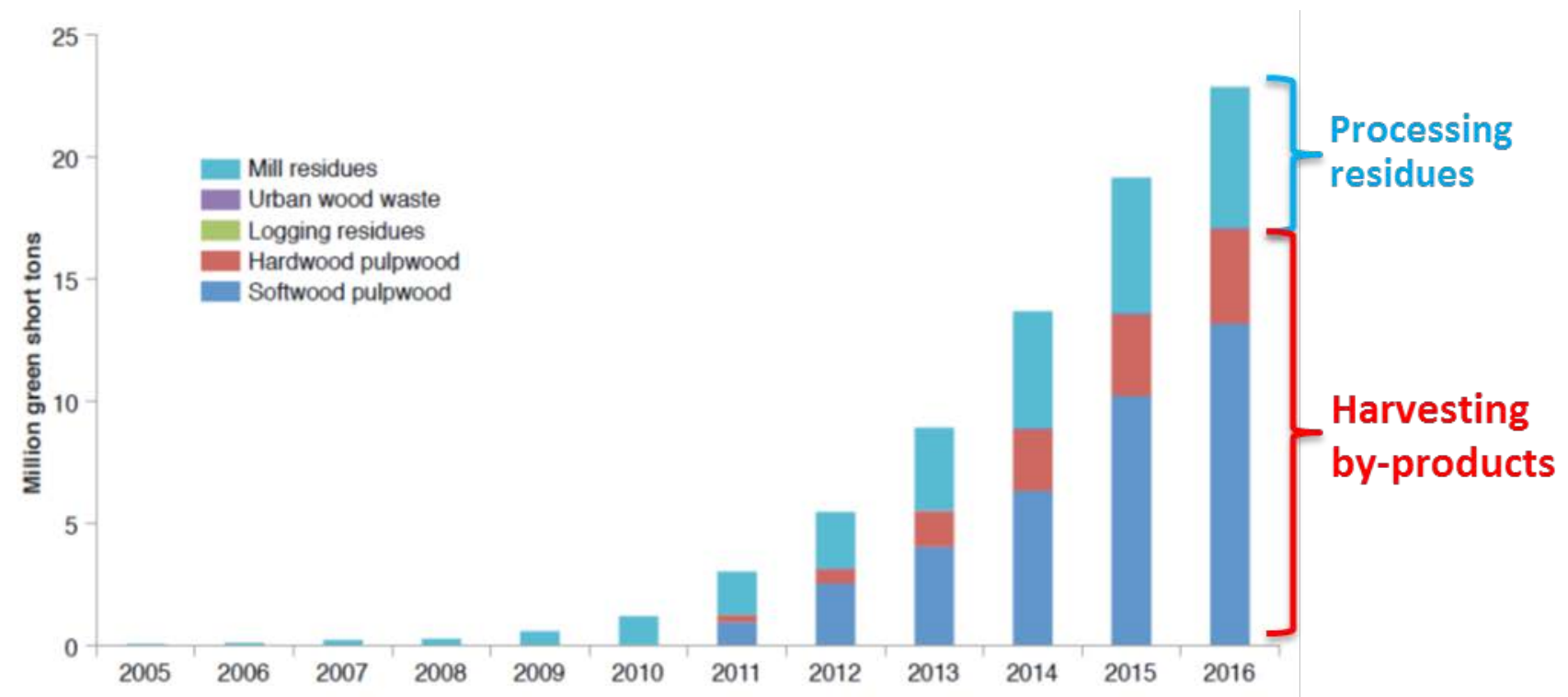

Figure 5. Actual and announced feedstock source for use in pellet production in the southern U.S. for 2005-2016 (Forisk Consulting in Abt et al. 2014).

Figure 6 shows the combined feedstock portfolio of two large pellet mills in the U.S. Southeast operated by Drax (Morehouse BioEnergy and Amite BioEnergy) with an individual capacity of 500,000 tons. Their plant level feedstock sourcing scheme reflects that of the wider U.S. Southeast pelleting industry.
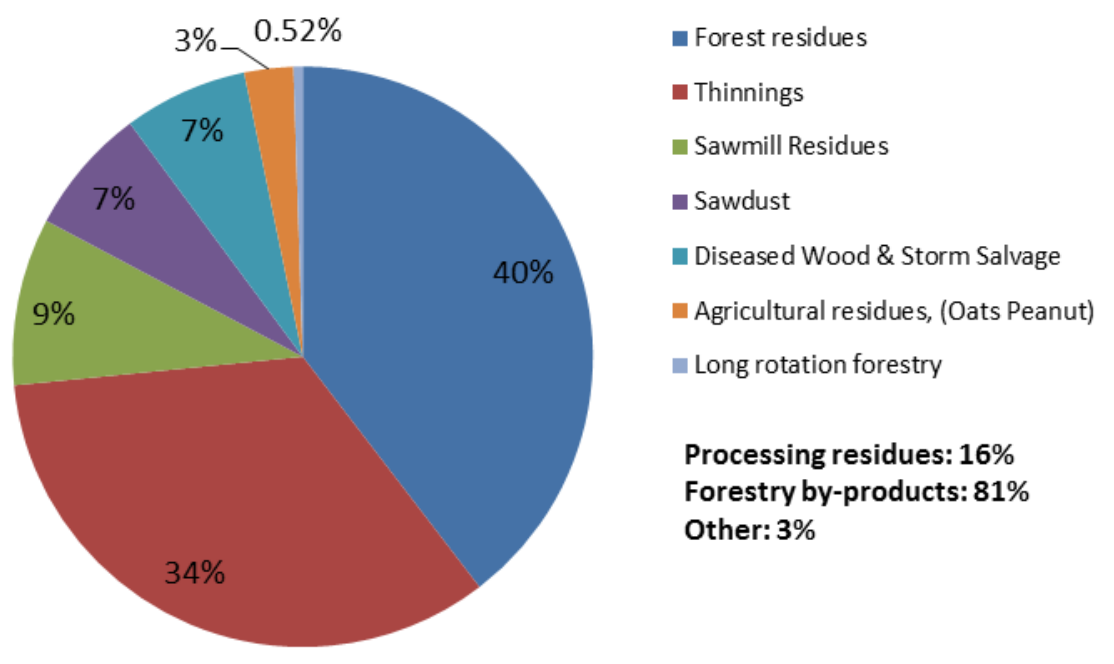

Figure 6. Drax US feedstock sourcing portfolio (http://www.drax.com/media/56583/biomass-supplyreport-2014.pdf).

Enviva Biomass, the largest U.S. based producer with a portfolio of seven plants totaling a combined capacity of 3 million tons annually is about to disclose their feedstock sourcing data on their website (launch date not yet clear). According to Jennifer Jenkins, Enviva’s Vice President and Chief 
Sustainability Officer (Personal Communication), the company's sourcing stream is made up of $44 \%$ low-grade wood fiber from mixed pine-hardwood stands, 24\% thinnings from pine plantations, 24\% secondary residues (wood processing industry), plus 1\% landscaping and other (7\%) material. In total, the company sources $59 \%$ hardwood and $41 \%$ softwood through suppliers who deliver fiber from privatelyowned forests and directly from sawmills and other wood industry manufacturers. The average age of the supplied wood is 36 years.

\subsection{Feedstock value and price trends}

\section{Feedstock value}

The most valuable harvest fraction in forestry is veneer logs, followed by sawtimber, chip-n-saw and pulpwood; respectively. Unless forests are owned by specific industry operations and grown solely for a specific assortment, e.g., short rotation pulpwood plantations, forest management and harvest timing are usually driven to maximize the most valuable fractions. Feedstock for pulp and paper, OSB or wood pellets are often not the most desired product of silviculture objectives, but can provide additional revenue streams. Thinning operations, e.g., specifically target the optimization of stands for sawtimber value.

During the decline of the U.S. housing market and following recession, available pulpwood and sawmill residual chip supply declined significantly in the U.S. South for both soft- and hardwood (Forest2Market 2015). This decline has increased demand (and stumpage prices) for pulpwood and residuals (Forest2Market 2015).

The value of these individual wood assortments are connected to the buying industry's willingness-to-pay (WTP), which is defined by plant economics and end product market value, e.g., sawn timber. It has been calculated that across the U.S. Southeast, the panelboard and pulp and paper industry can typically afford to pay a higher price for feedstock than wood pellet or bioenergy operations (Figure 7). Fiber costs including transport to the wood pellet plant gate usually range around $\$ 45$ to $\$ 70$ per dry ton and make up around a third of the total wood pellet production costs (at plant gate) (see also Table 3).

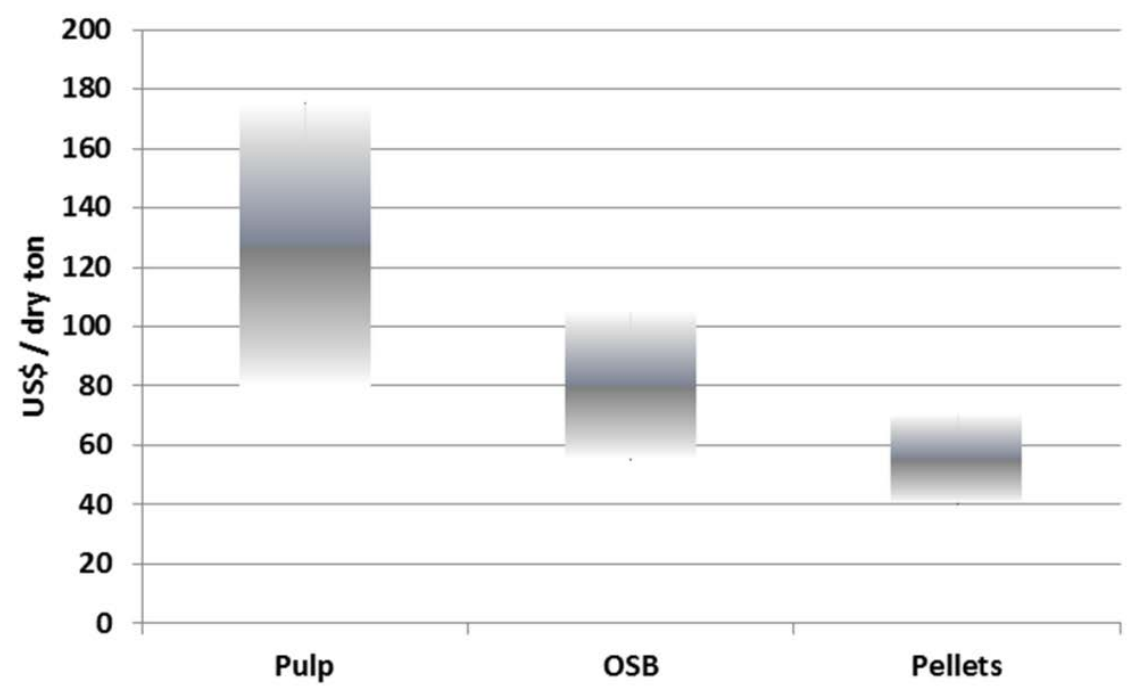

Figure 7. Upper ranges of the willingness-to-pay for feedstock of different wood product industries in the U.S. Southeast (Teir 2013).

Project information in accordance with DOE Contract No. DE-AC07-05ID1451 Do Not Further Disclose or Disseminate. 


\section{Production costs}

Table 3. Pellet supply costs based on US Southeast wood pellet data and herbaceous feedstock supply prices (\$/ton).

\begin{tabular}{|c|c|c|c|c|c|c|}
\hline & $\begin{array}{r}\text { Average } \\
\text { share }\end{array}$ & $\begin{array}{c}\text { Wood } \\
\text { pellet } \\
\text { (lower } \\
\text { range) }\end{array}$ & $\begin{array}{r}\text { Wood } \\
\text { pellet } \\
\text { (upper } \\
\text { range) }\end{array}$ & $\begin{array}{l}\text { Corn } \\
\text { stover } \\
\text { pellets } \\
\text { (lower } \\
\text { range) }\end{array}$ & $\begin{array}{l}\text { Straw } \\
\text { pellets }\end{array}$ & $\begin{array}{r}\text { Corn } \\
\text { stover } \\
\text { pellets } \\
\text { (upper } \\
\text { range) }\end{array}$ \\
\hline Fiber cost & $27 \%$ & $\$ 35$ & $\$ 45$ & \multirow{2}{*}{$\$ 45$} & \multirow{2}{*}{$\$ 68$} & \multirow{2}{*}{$\$ 54$} \\
\hline Fiber transport & $11 \%$ & $\$ 15$ & $\$ 19$ & & & \\
\hline Pelleting OPEX & $15 \%$ & $\$ 20$ & $\$ 23$ & $\$ 22$ & $\$ 22$ & $\$ 22$ \\
\hline Pelleting CAPEX & $23 \%$ & $\$ 34$ & $\$ 34$ & $\$ 34$ & $\$ 34$ & $\$ 34$ \\
\hline Plant gate & $76 \%$ & $\$ 105$ & $\$ 120$ & $\$ 101$ & $\$ 124$ & $\$ 110$ \\
\hline Mill to port & $5 \%$ & $\$ 7$ & $\$ 7$ & $\$ 7$ & $\$ 7$ & $\$ 7$ \\
\hline Port storage \& handling & $6 \%$ & $\$ 7$ & $\$ 11$ & $\$ 9$ & $\$ 9$ & $\$ 9$ \\
\hline FOB & $88 \%$ & $\$ 120$ & $\$ 138$ & $\$ 117$ & $\$ 140$ & $\$ 127$ \\
\hline Ocean freight \& handling & $12 \%$ & $\$ 16$ & $\$ 20$ & $\$ 18$ & $\$ 18$ & $\$ 18$ \\
\hline CIF-ARA & $100 \%$ & $\$ 136$ & $\$ 158$ & $\$ 136$ & $\$ 158$ & $\$ 145$ \\
\hline
\end{tabular}

Residential wood pellet market - domestic

Residential markets are supplied by bagged pellets, stacked on pallets for bulk distribution. Prices vary, but are typically in the range of $\$ 5$ (standard) to $\$ 7$ (premium) per 40 pound bag (18.14 kg), equaling $\$ 250$ to $\$ 350$ per ton (excl. tax) at a final user distribution center, e.g., supermarket.

\section{Industrial wood pellet market - export}

Historically, industrial wood pellets sold for \$130 to \$160 per ton at Amsterdam, Rotterdam, or Antwerp (ARA) harbors (CIF-price: Cost, Insurance and Freight). U.S. FOB (Free-On-Board) or FAS (FreeAlongside-Ship) export prices have ranged between \$115 and \$140 per ton in main distribution harbors along the Southeast (e.g., Savanna, GA, and Mobile, AL) (Table 3).

Wood pellet supply contracts between U.S. producers and European utilities have fixed prices (potentially linked to a price adaptation formula), are negotiated in US\$, and last typically 5-6 years (Keppler 2016, Peter-Paul Schouwenberg 2016). As such the recent drop in foreign exchange rates between the Euro and the US\$ did not have a negative impact on U.S. pellet producers as much as it possibly could have. However, production has slumped outside of these long-term supply contracts and the market has seen an oversupply in 2016. Current spot prices (CIF-ARA) for U.S. produced wood pellets are close to production costs (Figure 8). 


\section{Milestone Completion Report}

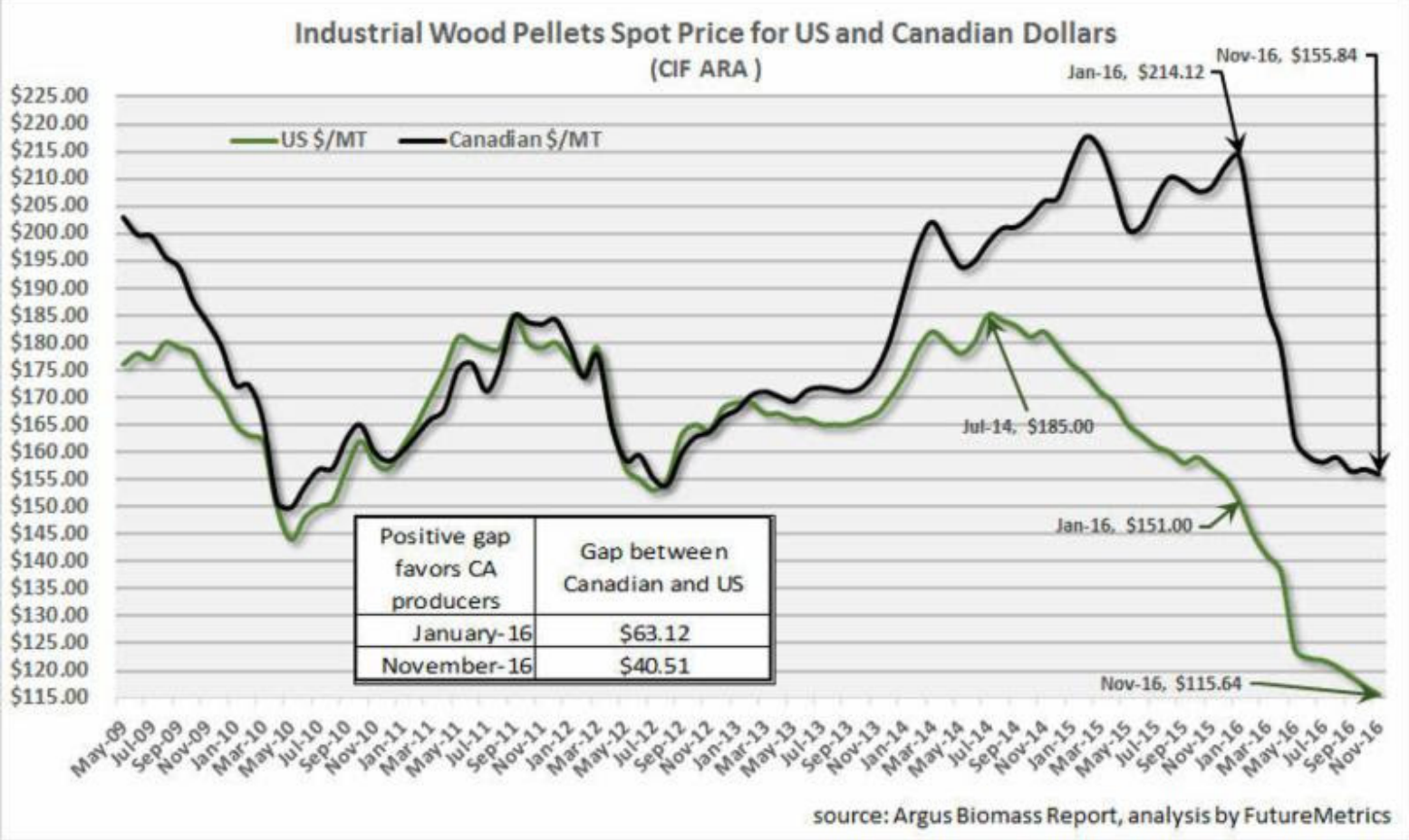

Figure 8. Industrial wood pellet spot prices in U.S. and Canadian Dollars (Source: FutureMetrics). 


\section{OTHER PELLETS}

\subsection{Herbaceous pellets}

Despite the fact that many other industries besides biofuel producers also desire input material to be easy to handle, quality controlled/on-spec, etc., there is very little herbaceous pellet production across the U.S. at this point. Nine operations are currently operating with a total capacity of roughly 336,000 tonnes (Table 4). This number takes individual producer information into account and is slightly higher than the estimates presented by Biomass-Magazine 2016.

Table 4. Agricultural residue pellet operations sorted by feedstock sourcing strategy.

\begin{tabular}{|c|c|c|c|c|c|c|}
\hline Company & State & Feedstock & $\begin{array}{l}\text { Capacity } \\
\text { (tons)* }\end{array}$ & Status* & Markets & $\begin{array}{r}\text { Feedstock } \\
\text { contracting }\end{array}$ \\
\hline Golden Peanut Co. & $\mathrm{AL}$ & Peanut husks & $\mathrm{n} / \mathrm{a}$ & $\mathrm{O}$ & Absorbent & \multirow{4}{*}{$\begin{array}{r}\text { Secondary waste } \\
\text { stream from } \\
\text { processing operation }\end{array}$} \\
\hline Golden Peanut Co. & GA & Peanut husks & $\mathrm{n} / \mathrm{a}$ & $\mathrm{O}$ & $\begin{array}{r}\text { Fertilizer } \\
\text { Heat \& power }\end{array}$ & \\
\hline International Pecan Co. & $\mathrm{TX}$ & Pecan shells & $\mathrm{n} / \mathrm{a}$ & $\mathrm{O}$ & $\mathrm{n} / \mathrm{a}$ & \\
\hline American Biocarbon & LA & $\begin{array}{l}\text { Sugarcane field } \\
\text { residues }\end{array}$ & $\begin{array}{r}10,000 \\
(200,000)\end{array}$ & $\begin{array}{r}\mathrm{O} \\
(\mathrm{P})\end{array}$ & $\begin{array}{l}\text { Heat \& power } \\
\text { (biocoal, steam } \\
\text { treated pellets) }\end{array}$ & \\
\hline Enginuity Worldwide & MO & Crop residues & 6,000 & $\mathrm{O}$ & $\begin{array}{r}\text { Animal feed } \\
\text { Soil amendment } \\
\text { Heat \& power }\end{array}$ & \multirow{5}{*}{$\begin{array}{r}\text { Ag crop \& residues } \\
\text { (contracted \& } \\
\text { affiliated/member) }\end{array}$} \\
\hline Pellet Technology USA & $\mathrm{NE}$ & Corn stover & 30,000 & $\mathrm{O}$ & $\begin{array}{r}\text { Animal feed } \\
\text { Heat \& power }\end{array}$ & \\
\hline Show Me Energy Coop & $\mathrm{MO}$ & Crop residues & 90,000 & $\mathrm{O}$ & $\begin{array}{r}\text { Heating } \\
\text { Animal bedding }\end{array}$ & \\
\hline Ernst Biomass & PA & Switchgrass & 25,000 & $\mathrm{O}$ & $\begin{array}{r}\text { Absorption } \\
\text { Animal bedding }\end{array}$ & \\
\hline Global Harvest Organics & $\mathrm{MO}$ & $\begin{array}{l}\text { Agricultural } \\
\text { residues }\end{array}$ & 10,000 & UC & $\begin{array}{r}\text { Soil amendment } \\
\text { Animal feed }\end{array}$ & \\
\hline Iowa Biomass Pelleting & IA & Crop Residue & 12,000 & $\mathrm{P}$ & $\mathrm{n} / \mathrm{a}$ & $\mathrm{n} / \mathrm{a}$ \\
\hline Enviro Energy & NY & $\begin{array}{l}\text { Agricultural } \\
\text { residues }\end{array}$ & 2,000 & $\mathrm{O}$ & $\mathrm{n} / \mathrm{a}$ & $\mathrm{n} / \mathrm{a}$ \\
\hline
\end{tabular}

*Note: not available (n/a), Operational (O), Under Construction (UC), Proposed (P),

Several distinctions can be made across the industry. Foremost, they differ in feedstock sourcing and contracting schemes. One line of operations relies on mill residues from the food processing industry (e.g., nuts and sugar). Others source agricultural harvesting residues directly through contracts with farmers. The end-markets are diverse and range from animal feed, to animal bedding (absorbents), soil amendment (fertilizer or biochar), and combustion processes (biocoal).

Show Me Energy ${ }^{\mathrm{f}}$ in Missouri is at present the largest operation. It is a farmer cooperative with a pelleting facility of 13.5 tonnes per hour (roughly 100,000 tons per year), which produces herbaceous pellets for energy use (heating of residential homes and broiler houses) and animal feed (cattle roughage extender). It had plans to also sell pellets (from cornstalks, grass straw, wheat and oat straw, milo stubble and

\footnotetext{
${ }^{\mathrm{f}}$ http://www.showmeenergycoop.com; https://vimeo.com/7337437 [October 11, 2016]. 
soybean stubble) to Kansas City Power and Light where they were aimed at being co-fired with coal for the production of electricity and the generation of Renewable Energy Credits. ${ }^{\mathrm{g}}$

Pellet Technology ${ }^{\mathrm{h}}$ of Nebraska currently has the second largest production and produces feed pellets made from corn stover and other herbaceous material (to improve digestability) for the domestic animal feed industry and combustion use. It contracts farmers within a 50 mile radius of the facility to supply 100,000 tons of stover annually.

American Biocarbon ${ }^{\mathrm{i}}$ in Louisiana is expected to become the largest herbaceous pelleting operation with a nameplate capacity of 200,000 tons per year. At present its pilot operation is at 10,000 tons annual capacity, producing torrefied pellets from sugarcane field residues. The future market for its large-scale facility would be European co-firing markets. Its geographic location allows access to large-scale oversea shipping routes. Its feedstock will be sourced in partnership with local sugar mills and their associated farmers.

\subsection{Feedstock portfolio, value and willingness-to-pay}

Current applications of corn stover are diverse but dominated by livestock co-feed. Due to the characteristics of corn stover (e.g., thick stalks), wheat straw is generally preferred as bedding material for larger animals. Other animal operations, e.g., poultry, do apply corn stover. However, the majority of US broiler production is outside the key corn producing states in the Midwest. Hence, different material is often applied (e.g., sawdust, shredded switchgrass, etc.) ${ }^{\mathrm{j}}$. Other niche applications for corn stover include mushroom cultivation substrates.

The major use of corn stover is on-farm. As such, most material does not transfer via an official market (as compared to, e.g., hay) and thus lacks transparency and official statistics. A general, annual value for corn stover is not available. Corn stover is a valuable winter feed option for healthy cattle and its value will differ whether it is left standing the field for grazing or harvested, baled, and sold to replace alternative feed sources.

One way to derive corn stover value is via an estimation of co-feed value against alternatives. Calculations by Iowa State University ${ }^{\mathrm{k}}$ under the assumptions of \$100/ton hay and \$200/ton DDGS feed prices, suggest that harvested corn stover as a feed alternative can have a value of up to \$63-77 per ton. Left standing in the field, the value is reduced to $\$ 20$-30 per ton.

A second way to estimate corn stover value is via prices at auctions. These are also automatically an indicator for the industry's willingness-to-pay. Prices at auctions should however be interpreted carefully as they vary with alternative feed prices at the time of the auction, the quality of the auctioned material, the location and the time of year the auction is held, as well as the year itself (which influences the total amount of available herbaceous material).

\footnotetext{
${ }^{\mathrm{g}}$ http://agebb.missouri.edu/agforest/archives/v12n2/gh4.htm [November 4, 2016].

${ }^{\mathrm{h}}$ http://www.pellettechnologyusa.com [November 8, 2016].

${ }^{\mathrm{i}}$ http://www.americanbiocarbon.com/ [October 11, 2016].

${ }^{\mathrm{j}}$ https://youtu.be/xmZJw_1Mt5w [November 9, 2016]

${ }^{\mathrm{k}}$ https://www.extension.iastate.edu/agdm/crops/html/a1-70.html [November 8, 2016].
} 
Auction data (grower payment plus delivery to auction) from Rock Valley Hay ${ }^{1}$ shows a weighted average price of $\$ 54 /$ ton of straw and $\$ 45 /$ ton (and a range of $\$ 20-70 /$ ton) of corn stalk and a total sale quantity of 2,967 tonnes for the month of February 2016. This data is in-line with USDA Hay Feed and Seed Weekly price reports ${ }^{\mathrm{m}}$ indicating a range of \$38-60/ton for corn stover. USDA Market Reports detail price structure for specific crops, e.g., wheat straw. Corn stalk was not available at the time this analysis was completed. Wheat straw prices vary significantly between years, as well as application and regions. For example, reported prices for 2014 erosion control material reached \$138/ton in California. In Alabama, due to its scarcity, wheat straw has reached prices of \$155/ton three consecutive years (20142016). Sale values of different feed options as presented in the USDA National Weekly Ag Energy Round-Up and the USDA National Hay, Feed \& Seed Weekly Summary. ${ }^{\mathrm{n}}$

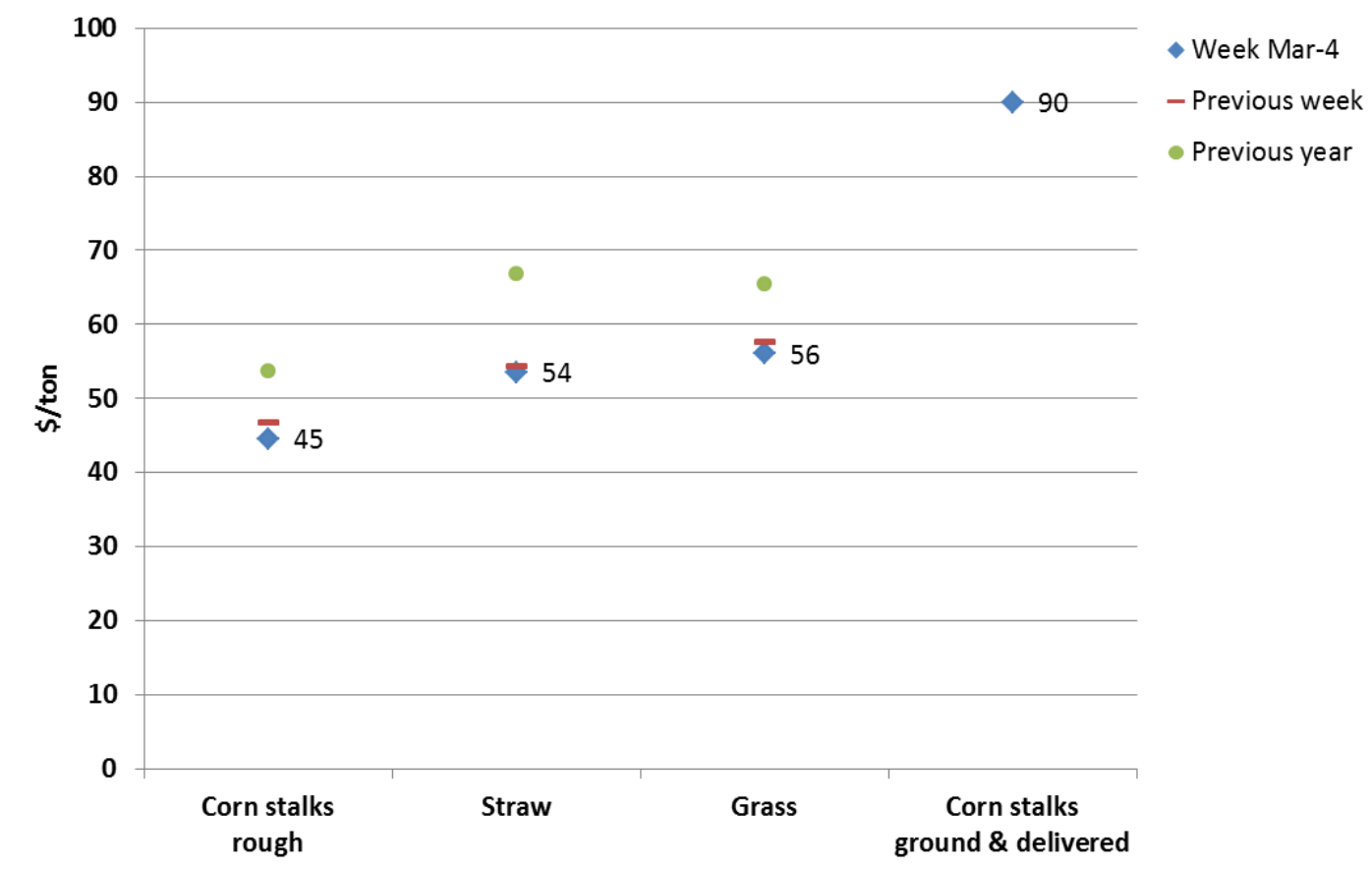

Figure 9. Average weekly sale values of different feed options reported for Iowa, Minnesota, Nebraska, South Dakota, Kansas, Missouri, and Illinois (Data: USDA).

\footnotetext{
${ }^{1}$ http://www.rockvalleyhay.com/site/mixedhay-bedding.html [November 2, 2016]

${ }^{\mathrm{m}}$ https://www.ams.usda.gov/market-news/custom-reports ; https://www.ams.usda.gov/market-news/hay-reports ; https://www.ams.usda.gov/market-news/bioenergy-market-news-reports [November 9, 2016].

${ }^{\mathrm{n}}$ https://www.ams.usda.gov/mnreports/lswfeedseed.pdf ; https://www.ams.usda.gov/mnreports/lswfeedseed.pdf [November 9, 2016].
}

Project information in accordance with DOE Contract No. DE-AC07-05ID1451 


\section{Idaho National Laboratory}

\section{U.S. TRADE BALANCE AND GLOBAL OUTLOOK}

\subsection{Domestic consumption}

U.S. biomass consumption for energy has increased by almost 2 trillion Btu (roughly 2 EJ) over the last decade (Figure 10). This increase, however, was observed solely in the liquid biofuels sector. Woody and waste biomass for energy use remained stagnant (although this overall trend may not be reflected across all regions within the U.S.).

Biomass energy consumed, by type (2002-13) trillion Btu

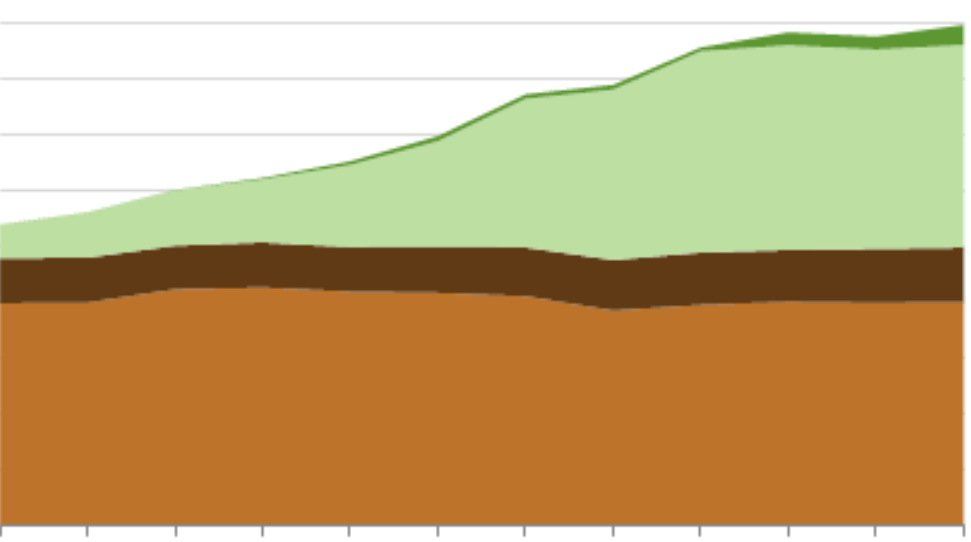

Figure 10. Biomass energy consumed by type between 2002-2013 (http://www.eia.gov/todayinenergy/detail.cfm?id=15451).

No official statistics on domestic wood pellet consumption exists. However, it can be approximated via the following formula: $C_{i}=P_{i}+I_{i}-E_{i}$

Where $\quad C_{i}$ : Consumption in year $i$

$P_{i}$ : Production in year (Sources: Lamers et al. 2012, FAOSTAT 2016)

$I_{i}$ : Imports in year i (Sources: Statistics-Canada 2016, USDA 2016)

$E_{i}$ : Exports in year i (Sources: EUROSTAT 2015, USDA 2016)

Table 5. Estimated domestic consumption based on production, import and export statistics (metric tonnes).

\begin{tabular}{|l|r|r|r|r|r|r|r|r|}
\hline & $\mathbf{2 0 0 8}$ & $\mathbf{2 0 0 9}$ & $\mathbf{2 0 1 0}$ & $\mathbf{2 0 1 1}$ & $\mathbf{2 0 1 2}$ & $\mathbf{2 0 1 3}$ & $\mathbf{2 0 1 4}$ & $\mathbf{2 0 1 5}$ \\
\hline$P_{i}$ & $1,800,000$ & $2,800,000$ & $3,000,000$ & $4,000,000$ & $5,100,000$ & $5,700,000$ & $6,900,000$ & $7,400,000$ \\
\hline$I_{i}$ & 440,000 & 293,000 & 40,000 & 50,000 & 86,736 & 152,442 & 219,987 & 207,172 \\
\hline$E_{i}$ & 490,000 & 577,742 & 794,955 & $1,081,834$ & $1,898,117$ & $2,882,423$ & $4,055,689$ & $4,668,552$ \\
\hline$C_{i}$ & $1,750,000$ & $2,515,258$ & $2,245,045$ & $2,968,166$ & $3,288,620$ & $2,970,019$ & $3,064,297$ & $2,938,620$ \\
\hline
\end{tabular}




\section{Milestone Completion Report}

The primary consumers of U.S.-produced wood pellets are export markets, accounting for 63\% in 2015. The remaining share is consumed domestically in residential heating. It is estimated that over 13 million wood heaters are in operational use across the U.S., the minority (roughly 10\%) of which are wood pellet stoves (Figure 11). Commercial use is limited and expected at under 1\% total consumption (Table 6).

U.S. biopower and/or -heat facilities are not known to use wood pellets in significant quantities. Rather, these installations are regionally integrated and make use of local wood waste fractions. A key reason is that - apart from state Renewable Portfolio Standards setting mandatory renewable electricity production levels for power companies - there are no U.S. incentive schemes which could close the gap between the oversea and domestic market willingness-to-pay (WTP). Hence, U.S. biopower and CHP installations are usually in the vicinity of wood processing industries or urban agglomerations where they can make use of construction and demolition wood (Figure 12, Figure 13).

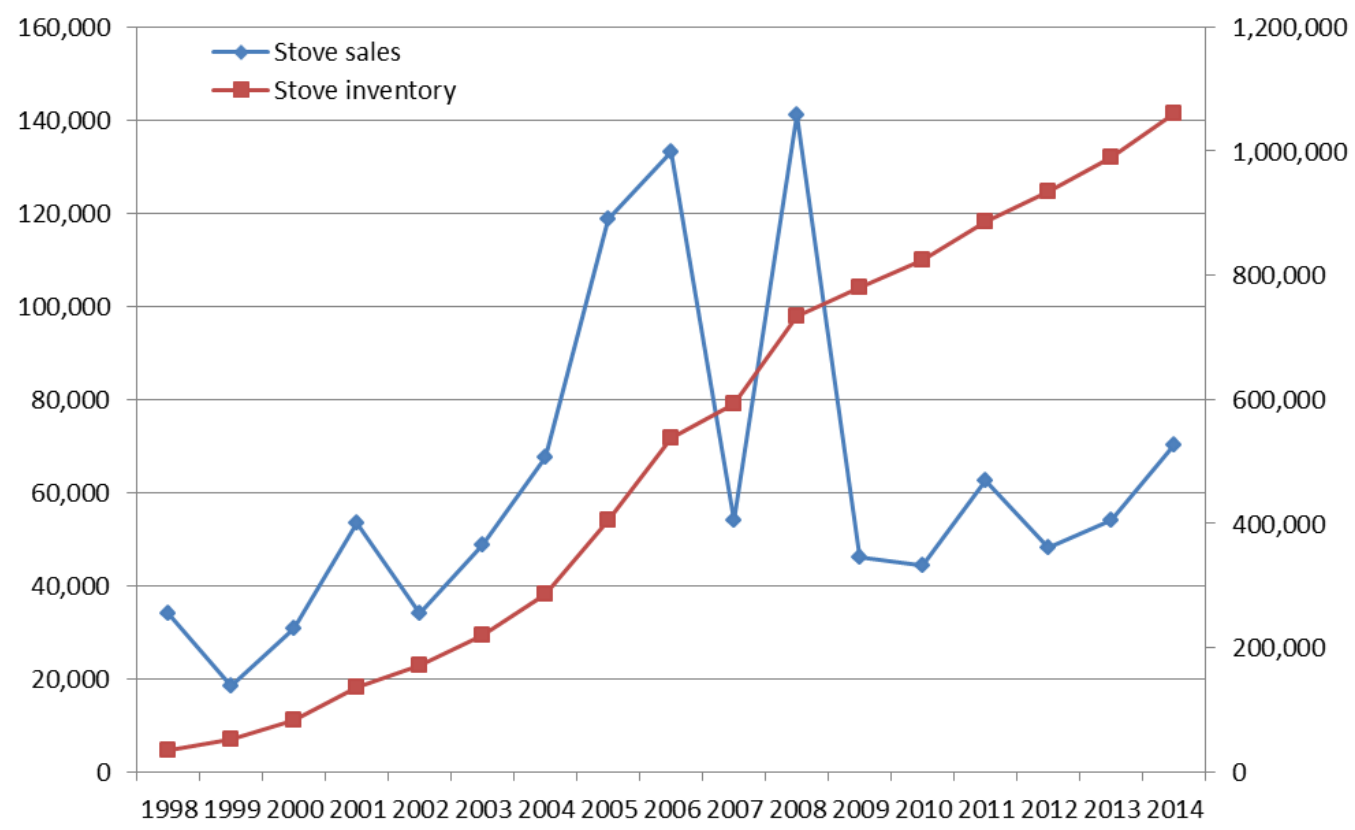

Figure 11. U.S. pellet stove sales (Source: Hearth, Patio, and Barbeque Association; http://www.biomassthermal.org/resource/PDFs/Fact\%20Sheet\%202.pdf; Personal Communication with Seth Walker, RISI). 


\section{Idaho National Laboratory}

Table 6. Wood and wood-derived fuel consumption by sector as projected in EIA 2016 (PJ).

\begin{tabular}{|l|r|r|r|r|r|}
\hline Peta-Joule & $\mathbf{2 0 1 2}$ & $\mathbf{2 0 1 3}$ & $\mathbf{2 0 1 4}$ & $\mathbf{2 0 1 5}$ & Comments \\
\hline Marketed Use (PJ) & & & & & \\
\hline >> Residential: Wood: Reference case & 468 & 615 & 646 & 498 & Fuelwood dominates \\
\hline >> Commercial: Biomass: Reference case & 112 & 127 & 127 & 127 & \\
\hline Electric Power Generation (PJ) & & & & & \\
\hline >> Dedicated Plants: Reference case & 109 & 122 & 114 & 117 & \\
\hline >> Co-firing: Reference case & 72 & 72 & 65 & 66 & \\
\hline Million tons (theoretical) & & & & & \\
\hline Marketed Use (Million tons) & & & & & \\
\hline >> Residential: Wood: Reference case & 29.6 & 38.8 & 40.8 & 31.4 & of which 10\% wood pellets \\
\hline >> Commercial: Biomass: Reference case & 7.0 & 8.0 & 8.0 & 8.0 & of which <1\% wood pellets \\
\hline Electric Power Generation (Million tons) & & & & & \\
\hline >> Dedicated Plants: Reference case & 6.9 & 7.8 & 7.2 & 7.3 & of which <1\% wood pellets \\
\hline >> Co-firing: Reference case & 4.6 & 4.6 & 4.1 & 4.2 & of which <1\% wood pellets \\
\hline $\begin{array}{l}\text { Calculated theoretical U.S. domestic } \\
\text { wood pellet consumption (Million tons) }\end{array}$ & 3.1 & 4.1 & 4.2 & 3.3 & Sum of estimates \\
\hline
\end{tabular}

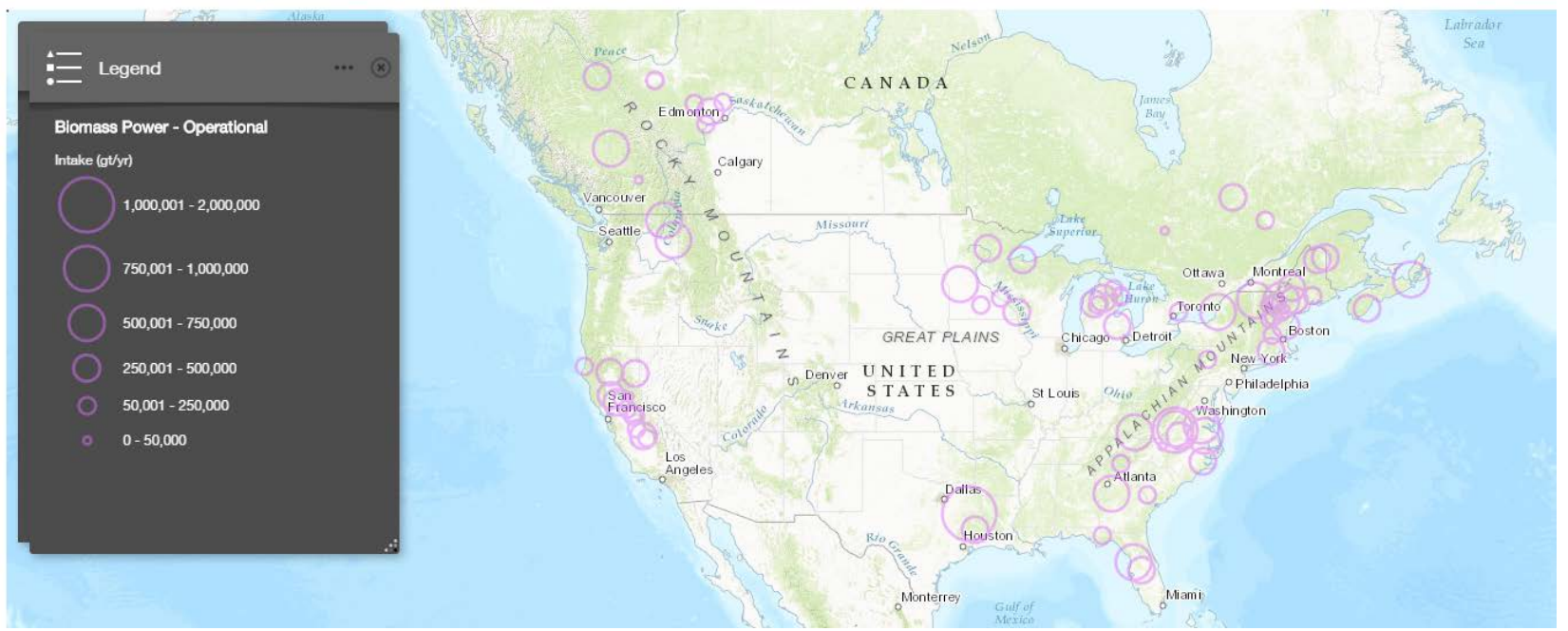

Figure 12. Biomass power operational (www.wood2energy.org). 


\section{Idaho National laboratory}

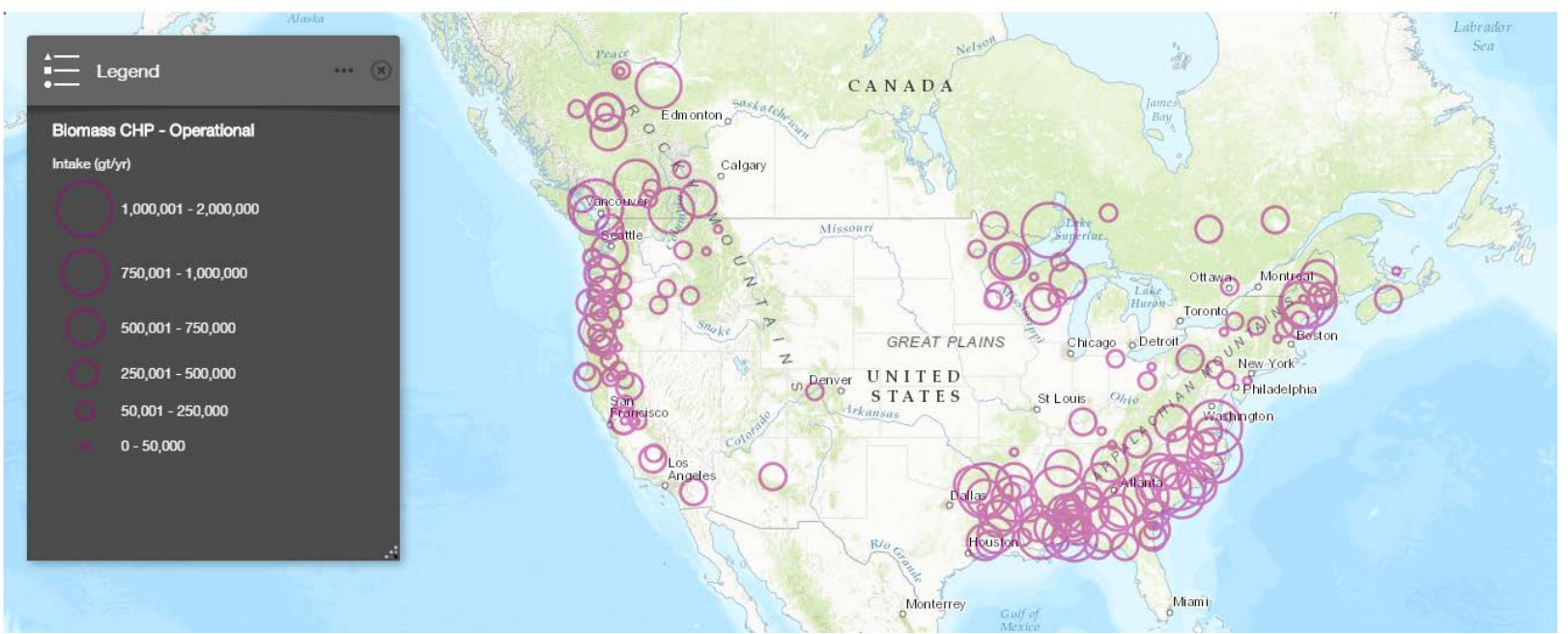

Figure 13. Biomass CHP operational (www.wood2energy.org).

\subsection{U.S. trade balance until 2015}

U.S. pellet production grew from around 2 million tons in 2008 to over 8 million tons by 2015 (Figure 14). Domestic consumption has remained relatively stable around 2-3.5 million tons. Annual cross-border trade with Canada is in the range of 250,000 tons and exports, $98 \%$ of which go to the EU, have reached almost two thirds of total production (Table 7).

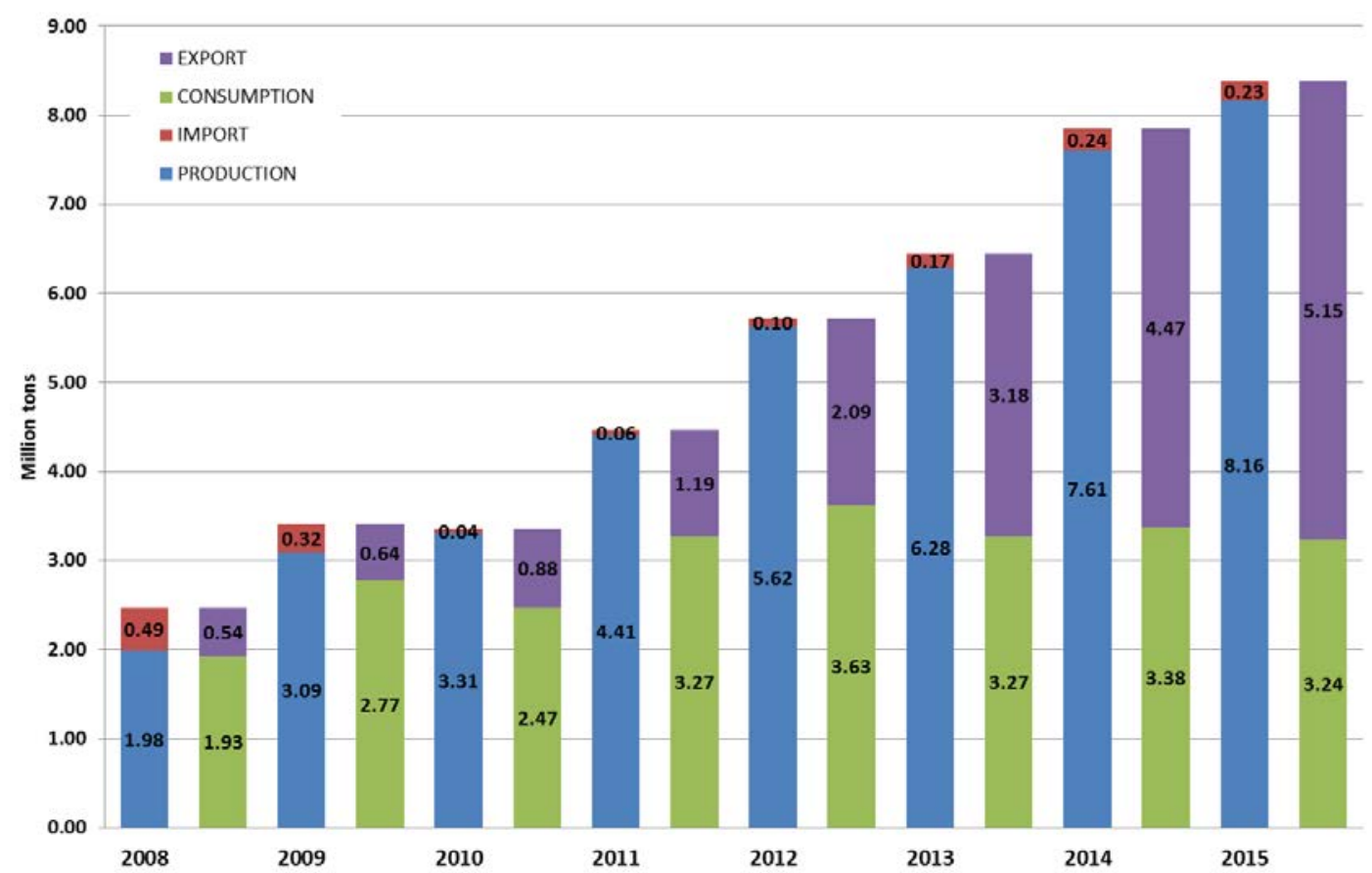

Figure 14. U.S. wood pellet production, consumption, imports and exports from 2008-2015. (Sources: Lamers et al. 2012, EUROSTAT 2015, FAOSTAT 2016, Statistics-Canada 2016, USDA 2016) 
Table 7. U.S. wood pellet exports in tons (USDA 2016).

\begin{tabular}{|l|r|r|r|r|}
\hline & $\mathbf{2 0 1 2}$ & $\mathbf{2 0 1 3}$ & $\mathbf{2 0 1 4}$ & $\mathbf{2 0 1 5}$ \\
\hline United Kingdom & 741,830 & $1,854,356$ & $3,265,913$ & $4,315,312$ \\
\hline Belgium (and Luxembourg) & 546,253 & 589,371 & 520,591 & 672,459 \\
\hline Netherlands & 550,231 & 196,667 & 330,287 & 70,126 \\
\hline France & 0 & 99 & 1,123 & 53,816 \\
\hline Canada & 36,051 & 23,787 & 25,209 & 24,639 \\
\hline South Korea & 28 & 37,038 & 60,578 & 4,186 \\
\hline Italy & 14,969 & 165,698 & 131,986 & 1,975 \\
\hline Denmark & 32,189 & 215,600 & 115,862 & 1,480 \\
\hline Sweden & 50,631 & 24,639 & 16,279 & 0 \\
\hline Other & 120,133 & 70,072 & 2,805 & 2,204 \\
\hline Total exports & $\mathbf{2 , 0 9 2 , 3 1 6}$ & $\mathbf{3 , 1 7 7 , 3 2 7}$ & $\mathbf{4 , 4 7 0 , 6 3 2}$ & $\mathbf{5 , 1 4 6 , 1 9 7}$ \\
\hline
\end{tabular}

\subsection{Global outlook until 2030}

Global wood pellet production capacity was around 20 million tons in 2015 with an addition 2.2 million tons under construction. The expected global production by 2017 is around 18 million tons which is likely to be soaked up by the market by 2018 the latest. This means that the current global oversupply (2016) will turn into an undersupply by 2018/2019 (definitely 2020) if no additional capacity is brought online.

Global demand for industrial wood pellets by 2015 was roughly 14.4 million tons and could grow up to 28 million tons by 2020. Global demand in combustion markets however will plateau (between 20252030) and is expected to decline, depending on future policies for biopower in North America and Asia (Bingham 2016, Keppler 2016, Strauss 2016, Wild 2016).

At present, the primary markets are industrial-sized heat and power production facilities in Europe, including Denmark, the Netherlands, Belgium, UK, and to some degree Sweden. In addition to 2015 demand levels, the following increases are expected in the coming years:

- UK: + 3.9 million tons (Lynemouth, MGT Power, Drax full conversion unit 1, minus Eon Ironbridge)

- Belgium: + 1.8 million tons by 2018 (Langerloo)

- Netherlands: + 1.7 million tons from late 2016 until mid-2017 (RWE/Essent, Engie) plus an additional increase to a total of 3.9 million tons by the end of 2017 (capped and limited to 8 years of subsidies)

- Denmark: + 1.2 million tons (Dong)

The underlying policies (e.g., carbon tax and/or coal phase-out) however are limited as wood pellet combustion in retrofitted coal-fired power plants is only seen as a transition to a low-carbon energy future. As a result, the EU demand is expected to plateau around 2027 (Pöyry 2014, Pöyry 2015, Bingham 2016). 
Demand increases in Asia are likely (Japan in particular), but the extent is yet unclear. Also, new demand markets will have suppliers compete for receiving long-term contracts. U.S. producers (from the Southeast) will need to compete with, e.g., Canadian producers in British Columbia, who already supply Asian markets today.

The future of wood pellet demand in North America is also somewhat uncertain. Canada has the potential to become a very large market as several provinces are aiming to phase-out coal (e.g., Alberta). If wood pellets are considered a viable option to reduce coal dependence and foster a respective phase-out by 2030, Alberta could have a demand of 25 million tons by 2029. Canada will likely consider supplying most of this demand from domestic producers.

Future U.S. demand will depend on state initiatives, as an implementation of the Clean Power Plan on Federal level is seen as unlikely. State initiatives and Renewable Portfolio Standards however could increase U.S. demand in the medium- (5yr) to long- (10 yr) term. Positive biomass activities in the U.S. include, e.g., Boardman, OR, the MISO Midwest grid operator foreseeing coal plant closures (and a capacity squeeze) by 2018, as well as developments in Maine where policy makers are starting to view biomass as a cost-efficient renewable strategy (Keppler 2016).

Figure 15 depicts one possible global demand outlook until 2030 taking into account information provided by utilities and pellet producers at the USIPA conference as well as market outlook studies by FutureMetrics and Hawkins Wright (Bingham 2016, Strauss 2016). The demand is lumpy as the individual demand parties are (partly very) large entities. Figure 16 breaks down the expected share of wood pellet production that would take place in the U.S. if the current supply shares to the respective demand countries are kept constant.

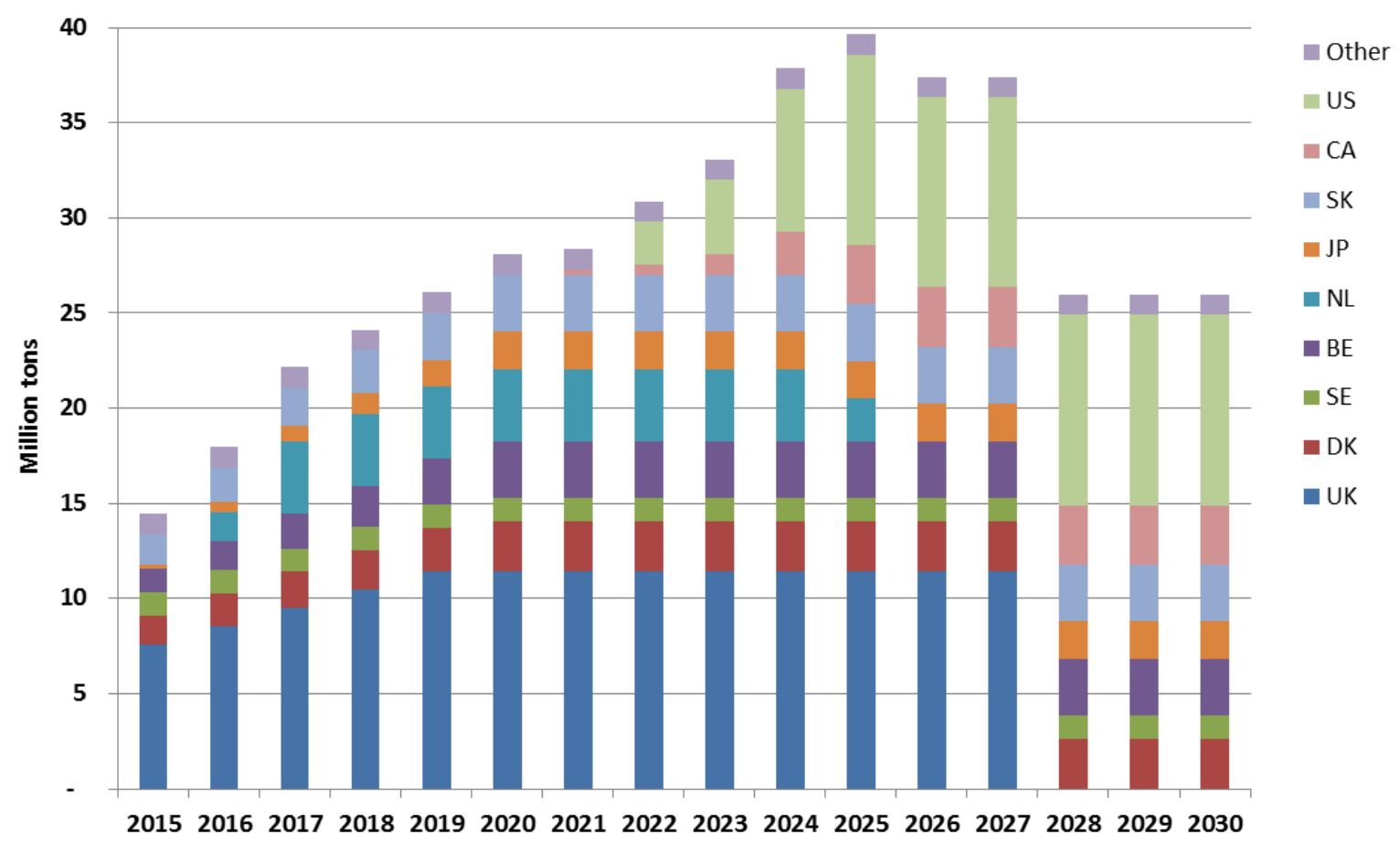

Figure 15. Past and expected global industrial wood pellet demand. 


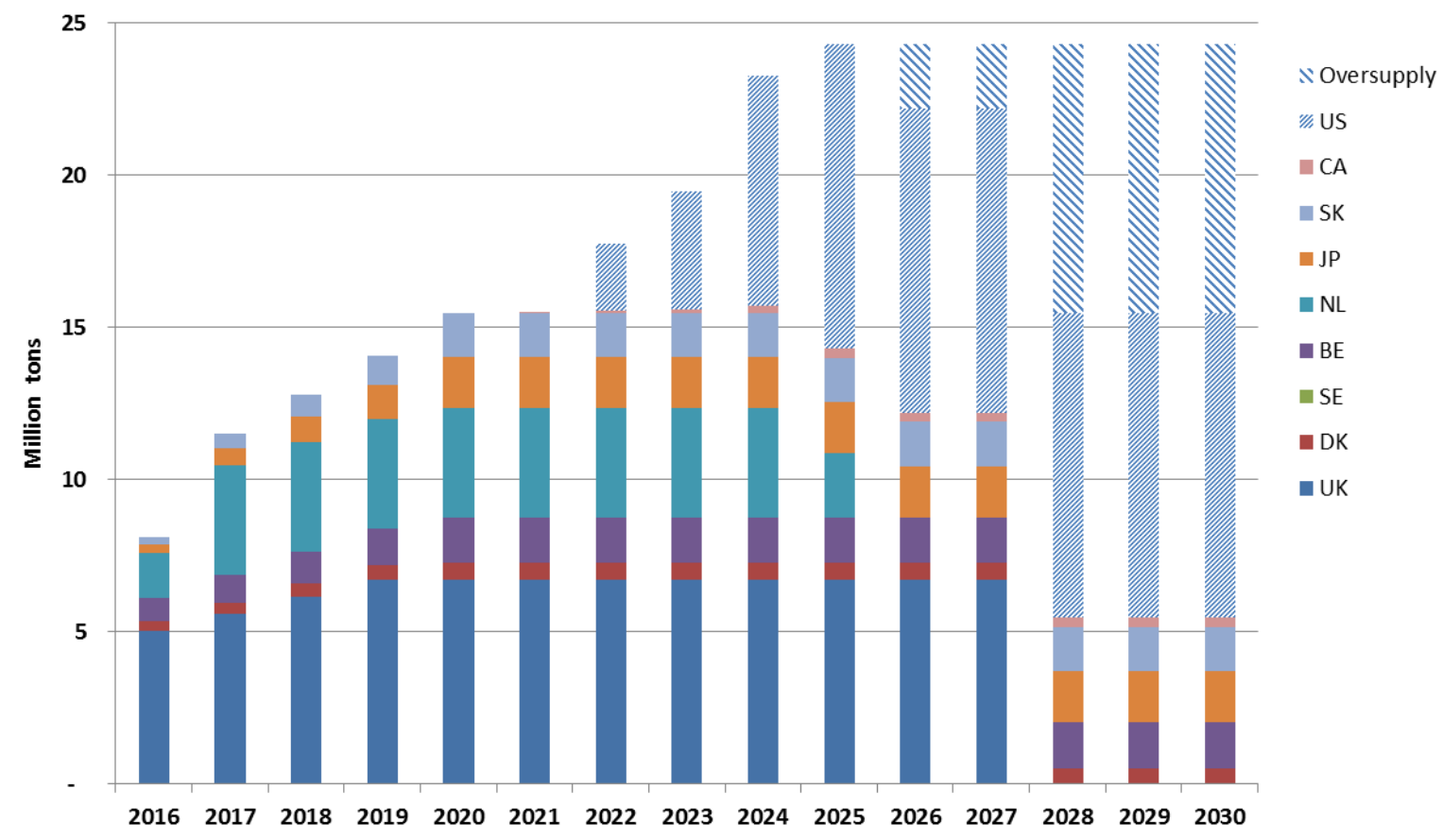

Figure 16. Expected U.S. industrial wood pellet production to fulfill part of the global demand.

\section{CONCLUSIONS}

The U.S. production of wood pellets has grown to over 8 million tons by 2015 (FAO 2016). The majority of the production capacity increase took place in the U.S. Southeast and is associated with industrial wood pellet production for export markets. In 2015, over 5 million tons were exported, 99\% of which went to EU markets (84\% to the UK alone) (EUROSTAT 2015, FAOSTAT 2016, USDA 2016). The production and consumption growth of U.S. residential wood pellets has been slow in comparison. The industrial and residential wood pellet markets are beginning to merge slowly, but production excess (e.g., in 2015 and 2016) in the industrial wood pellet segment could not be fully absorbed by domestic or oversea residential markets.

The main growth path for U.S. wood pellet production is still seen to lie in oversea markets (Bingham 2016, Strauss 2016). Demand increases for industrial pellets are projected to occur within the next years in Europe (Netherlands, Denmark, UK, Belgium) and Asia (predominantly Japan). At the same time, subsidy schemes in Europe are also bound to be phased out within the next decade. U.S. suppliers will have to compete with other supply regions (e.g., Western Canada to Asia) in the long-term, and are already focusing on selling more and more into non-subsidized markets such as biochemicals, absorbents, and soil amendments (Keppler 2016). An outlook of U.S. industrial wood pellet production under a potential growth in U.S. biopower demand and a lack thereof shows a wood pellet oversupply of 9-10 million tons by 2030, equaling roughly 12.5 million tons of production capacity, 20-30 large-scale plants, or 15 million green tons of woody biomass.

Once the U.S. production of wood pellets outgrows combustion market demand (which will plateau even with a domestic expansion of biopower) the industry will require additional outlets to avoid a structural 
decline and bankruptcy. This will create a resource push and cost reduction, driving the development of a U.S. cellulosic biofuels industry.

Facing record level U.S. corn production and end-market saturation, the corn industry (in conjunction with a phase-out of MTBE and the RFS) essentially pushed the establishment of a corn ethanol market. It is expected that - in similar fashion - a cellulosic biofuel market can be pushed into existence through the necessity of a domestic feedstock supply industry to tap into additional market outlets for their product. Without a liquid (in market terms) intermediate cellulosic feedstock market, future conversion industries will have a tendency to attach themselves to other, already existing feedstock markets such as bio-oil, starch or sugar. The export-oriented wood pellet industry is seen as the most promising leverage point to grow a respective feedstock market which could create a resource push and facilitate the expansion of a domestic cellulosic biofuel industry. Several conditions point into this direction. First, wood pellets fulfill the basic requirements of a commodity good and respective market:

- Standardized product: chemical and physical homogeneity within specifications

- Bulk transport / logistics capability: Stable and storable, durable and flowable, high bulk density

- Intermediate good, fungible across multiple markets: combustion (heat and/or power, residential and industrial scale), absorbents (chemical, oil and gas industry, animal bedding), biochemical, biofuel

- Physical trade is based on a mix of long-term and spot market agreements; the market is in a transition to become more competitive and liquid (ease to match a buyer and seller)

Second, the primary markets for U.S. wood pellets are expected to plateau around 2027 (taking into account new market growth in Europe and Asia). Additional demand could come from within the U.S., depending on state-level implementation of the CPP and RPS. Canada is also expected to increase cofiring capacities but will most likely focus on regional biomass supply. To avoid stagnation and decline the industry will have to start supplying non-combustion markets and become more cost-competitive.

Also, a growth and continuation of the wood pellet industry is strongly supported from the grower/resource base. The USFS, forest industry associations, and forest owners alike state that the pellet industry creates additional demand needed to keep forests in working condition due to the structural decline in the wood products industry and the slow recovery of the U.S. housing market. The main alternative for private forest owners is land clearance for urbanization, which could reduce the socioeconomic benefits associated with the forest industry in rural areas that have already suffered under the structural decline of the wood products sector. This aspect is relevant for constituents as well as policy makers.

\section{REFERENCES}

Abt, K. L., R. C. Abt, C. S. Galik and K. E. Skog (2014). Effect of policies on pellet production and forests in the U.S. South: a technical document supporting the Forest Service update of the 2010 RPA Assessment. USFS. Asheville, NC, USA, US Department of Agriculture Forest Service, Southern Research Station. Gen. Tech. Rep. SRS-202: 33. Retrieved from

http://www.srs.fs.usda.gov/pubs/gtr/gtr_srs202.pdf, [September 2, 2015].

Bingham, J. (2016). The global outlook for wood pellet markets: What does the future hold? USIPA Exporting Pellets, Miami, FL, USA, Hawkins Wright.

Biomass-Magazine (2016). Pellet Plant Producer List. Retrieved from

Project information in accordance with DOE Contract No. DE-AC07-05ID1451 Do Not Further Disclose or Disseminate. 
http://biomassmagazine.com/plants/listplants/pellet/US/, [September 19, 2016].

Cohn, N. (2016). Personal Communication. USIPA - Exporting Pellets, Miami, FL, USA, American Biocarbon.

EIA (2016). Annual Energy Outlook. Washington DC, USA, US Energy Information Administration (EIA). Retrieved from http://www.eia.gov/forecasts/aeo/, [15 September 2016].

EUROSTAT (2015). Data Explorer. Brussels, Belgium, Eurostat. Retrieved from http://epp.eurostat.ec.europa.eu/portal/page/portal/statistics/search database, [November 30, 2015].

FAO (2016). FAOSTAT - Forestry Production and Trade. Rome, Italy, Food and Agriculture Organization of the United Nations. Retrieved from http://faostat3.fao.org/download/F/FO/E, [February 2016].

FAOSTAT (2016). Statistics Division. Rome, Italy, Food and Agriculture Organization of the United Nations. Retrieved from http://faostat3.fao.org/home/E, [September 28, 2016].

Forest2Market (2015). Wood Supply Market Trends in the US South: 1995 - 2015. Charlotte, NC, USA, Forest2Market analysis for National Alliance of Forest Owners, US Endowment for Forestry and Communities, US Industrial Pellet Association. Retrieved from http://www.nafoalliance.org/images/issues/pellets/Forest2Market_USSouthWoodSupplyTrends.pdf, [November 22, 2015].

Keppler, J. (2016). Introduction to the USIPA - Exporting Pellets 2016 Conference. USIPA - Exporting Pellets, Miami, FL, USA, Enviva.

Lamers, P., M. Junginger, C. Hamelinck and A. Faaij (2012). "Developments in international solid biofuel trade - an analysis of volumes, policies, and market factors." Renewable \& Sustainable Energy Reviews 16(5): 3176-3199.

Peter-Paul Schouwenberg (2016). Personal Communication - Environment, Regulatory Affairs, New Energy for RWE/Essent. USIPA - Exporting Pellets, Miami, FL, USA, RWE/Essent.

Pöyry (2014). The dynamics of global pellet markets. 4. Central European Biomass Conference. S. Mergner, Pöyry Management Consulting. Retrieved from http://www.cebc.at/de/service/praesentationen/wba-workshop-weltweite-maerkte-fuerbiomasse/?eID=dam frontend push\&docID=2272, [January 2014].

Pöyry (2015). The dynamics of the global wood pellet industry moving forward. Nordic Baltic Bioenergy Conference. A. Gemmel, Pöyry Management Consulting. Retrieved from https://nordicbalticbioenergy.eu/, [July 2015].

Statistics-Canada (2016). Canadian International Merchandise Trade Database. Ottawa, Ontario, Canada. Retrieved from http://www5.statcan.gc.ca/cimt-cicm/searchescherchers?lang=eng\&searchStr $=4401 \&$ ref Yr $=2012 \&$ refMonth $=3 \&$ freq=6\&countryId=999\&provId $=1$ , [September 28, 2016].

Strauss, W. (2016). Industrial Wood Pellets in Japan - Market Drivers and Potential Demand. USIPA Exporting Pellets, Miami, FL, USA, FutureMetrics.

Teir, A. (2013). Views on the Atlantic basin industrial pellet market up to 2025. Pöyry management consulting. World biomass to power markets, Amsterdam, 16 May

USDA (2016). Global Agricultural Trade System (GATS). Washington DC, USA, US Department of Agriculture, Foreign Agricultural Service. Retrieved from http://www.fas.usda.gov/gats/default.aspx [September 28, 2016].

Wild, M. (2016). Personal Communication - President International Biomass Torrefaction Council. USIPA - Exporting Pellets, Miami, FL, USA, Wild \& Partners. 


\section{APPENDIX}

Table 8. States per region.

\begin{tabular}{|l|l|}
\hline Region & States \\
\hline Northwest (NW) & AK; ID; MT; OR; WA \\
\hline Southwest (SW) & AZ; CA; CO; NM; UT; WY \\
\hline Midwest (MW) & IA; IN; MI; MN; MO; NE; SD; WI \\
\hline Northeast (NE) & ME; NH; NY; OH; PA; VT \\
\hline Southeast (SE) & AL; AR; FL; GA; KY; LA; MS; NC; SC; TN; TX; VA; WV \\
\hline
\end{tabular}

Table 9. Operational U.S. wood pellet plant list by capacity (Biomass-Magazine 2016).

\begin{tabular}{|c|c|c|c|}
\hline Name & State & Feedstock & Capacity (tons per year) \\
\hline Golden Peanut Co. - Headland & $\mathrm{AL}$ & $\mathrm{Ag}$ & Undisclosed \\
\hline Golden Peanut Co. - Dawson & GA & $\mathrm{Ag}$ & Undisclosed \\
\hline Wood Pellet Coop & MN & Hardwood & Undisclosed \\
\hline$\underline{\text { Appalachian Wood Pellets }}$ & WV & Hardwood & Undisclosed \\
\hline Woodgrain Millwork Inc. & OR & Softwood & Undisclosed \\
\hline International Pecan Company & $\mathrm{TX}$ & Ag & Undisclosed \\
\hline$\underline{\text { Snow Timber Pellets LLC }}$ & WI & & 15 \\
\hline Hearthside Wood Pellets & NY & Hardwood & 700 \\
\hline Wolverine Hardwood Pellets & MI & Hardwood & 750 \\
\hline Phoenix Resources LLC & MI & Hardwood and Softwood & 900 \\
\hline Enviro Energy LLC & NY & $\mathrm{Ag}$ & 1,800 \\
\hline Hannas Candle Company & AR & & 2,000 \\
\hline Pellet Technology USA & $\mathrm{NE}$ & $\mathrm{Ag}$ & 2,500 \\
\hline Lemhi Valley Pellets & ID & Hardwood and Softwood & 2,600 \\
\hline Pellheat Inc. & PA & Hardwood & 5,000 \\
\hline Penn Wood Products Inc. & PA & Hardwood & 5,000 \\
\hline Bearlodge Forest Products & WY & Softwood & 5,000 \\
\hline Enginuity Worldwide LLC & MO & $\mathrm{Ag}$ & 6,000 \\
\hline Mt. Taylor Manufacturing - Pellet Mill & NM & Hardwood and Softwood & 6,000 \\
\hline Mt. Taylor Manufacturing & NM & Hardwood and Softwood & 6,000 \\
\hline Essex Pallet \& Pellet & NY & Hardwood and Softwood & 6,000 \\
\hline Associated Harvest Inc. & NY & Hardwood & 8,000 \\
\hline Log Hard Premium Pellets Inc. & PA & Hardwood & 8,000 \\
\hline Alexander Energy Inc. & PA & Hardwood & 8,500 \\
\hline Vulcan Wood Products & MI & Hardwood and Softwood & 9,000 \\
\hline
\end{tabular}

Project information in accordance with DOE Contract No. DE-AC07-05ID1451 Do Not Further Disclose or Disseminate. 


\begin{tabular}{|c|c|c|c|}
\hline American Biocarbon - White Castle & LA & Crop Residue & 10,000 \\
\hline Rocky Canyon Pellet Co. & ID & Hardwood and Softwood & 10,000 \\
\hline Woodscape of Utah & UT & Hardwood and Softwood & 10,000 \\
\hline American Pellet Company & MI & Hardwood and Softwood & 12,000 \\
\hline Southern Kentucky Pellet Mill Inc. & KY & Hardwood & 12,000 \\
\hline Kingdom Biofuels & PA & & 12,000 \\
\hline Southern Indiana Hardwoods & IN & Hardwood & 13,000 \\
\hline Show Me Energy Cooperative & $\mathrm{MO}$ & Biomass Crops & 15,000 \\
\hline Koetter \& Smith Inc. & IN & Hardwood & 15,000 \\
\hline Jensen Lumber Co. & ID & Softwood & 15,000 \\
\hline Vermont Wood Pellet Co. LLC & VT & Softwood & 16,600 \\
\hline Green Friendly Pellets LLC & MN & Hardwood & 17,000 \\
\hline$\underline{\text { G-Pel International }}$ & FL & & 17,000 \\
\hline Southwest Renewable Resources & $\mathrm{AZ}$ & Softwood & 18,000 \\
\hline Environmental Energy Partners LLC & $\mathrm{CO}$ & Softwood & 18,000 \\
\hline Horizon Biofuels Inc. & $\mathrm{NE}$ & Hardwood and Softwood & 20,000 \\
\hline Blue Mountain Lumber Products & OR & Hardwood and Softwood & 20,000 \\
\hline Malheur Pellet Mill & OR & Softwood & 20,000 \\
\hline Frank Pellets & OR & Softwood & 21,000 \\
\hline Maeder Brothers Quality Wood Pellets Inc. & MI & Hardwood & 22,000 \\
\hline American Wood Fibers - Wisconsin & WI & Hardwood and Softwood & 25,000 \\
\hline Ernst Biomass & PA & Biomass Crops & 25,000 \\
\hline Isabella Pellet & MI & Hardwood and Softwood & 25,000 \\
\hline Turman Hardwood Pellets & VA & Hardwood & 28,000 \\
\hline$\underline{\text { ProPellet }}$ & MN & Softwood & 28,000 \\
\hline Hassell \& Hughes Lumber Company & $\mathrm{TN}$ & Hardwood & 30,000 \\
\hline West Oregon Wood Products - Banks & OR & Softwood & 30,000 \\
\hline Phoenix Recycling & IA & & 30,000 \\
\hline EB Clean Energy Ltd. - Boardman & OR & & 30,000 \\
\hline Kirtland Products LLC & MI & Hardwood and Softwood & 35,000 \\
\hline Superior Pellet Fuels LLC & $\mathrm{AK}$ & Softwood & 35,000 \\
\hline Equustock - Clare & MI & Hardwood and Softwood & 36,000 \\
\hline Wood Pellets C\&C Smith Lumber & PA & Hardwood & 36,000 \\
\hline Manke Lumber Company & WA & Softwood & 38,000 \\
\hline Northeast Pellets LLC & ME & Hardwood and Softwood & 40,000 \\
\hline Equustock - Troy & VA & Hardwood and Softwood & 40,000 \\
\hline Dejno's Inc. & WI & Hardwood and Softwood & 40,000 \\
\hline Pacific Pellet LLC & OR & Hardwood & 40,000 \\
\hline Henry County Hardwoods Inc. & $\mathrm{TN}$ & Hardwood & 40,000 \\
\hline
\end{tabular}

Project information in accordance with DOE Contract No. DE-AC07-05ID1451 Do Not Further Disclose or Disseminate. 


\begin{tabular}{|c|c|c|c|}
\hline$\underline{\text { O'Malley Wood Pellets }}$ & VA & Hardwood & 40,000 \\
\hline Equustock - Montebrook & FL & Softwood & 40,000 \\
\hline Western Wood Products Inc. & NM & Softwood & 40,000 \\
\hline Bear Mountain Forest Products - Cascade Locks & OR & Softwood & 40,000 \\
\hline Patterson Wood Products Inc. & $\mathrm{TX}$ & Softwood & 40,000 \\
\hline Zilkha Biomass - Crockett & TX & Hardwood and Softwood & 44,000 \\
\hline Barefoot Pellet Company & $\mathrm{PA}$ & Hardwood & 45,000 \\
\hline American Wood Fibers - Circleville & $\mathrm{OH}$ & Hardwood and Softwood & 50,000 \\
\hline Tri State Biofuels LLC & PA & Hardwood and Softwood & 50,000 \\
\hline Fiber Resources Inc. & $\mathrm{AR}$ & Hardwood & 50,000 \\
\hline Michigan Wood Fuels & MI & Hardwood & 50,000 \\
\hline Instantheat Wood Pellets Inc. & NY & Hardwood & 50,000 \\
\hline Greene Team Pellet Fuel Company & PA & Hardwood & 50,000 \\
\hline$\underline{\text { PA Pellets }}$ & PA & Hardwood & 50,000 \\
\hline Pellet America Corp. & WI & Paper Waste & 50,000 \\
\hline North Idaho Energy Logs - Moyie Springs & ID & Softwood & 50,000 \\
\hline West Oregon Wood Products - Columbia City & OR & Softwood & 50,000 \\
\hline LowCountry Biomass & SC & Softwood & 50,000 \\
\hline Potomac Supply LLC & VA & Softwood & 50,000 \\
\hline$\underline{\text { Pacific Coast Pellets }}$ & WA & Softwood & 50,000 \\
\hline Dover Resources Inc. & CA & Woody Biomass & 50,000 \\
\hline$\underline{\text { Somerset Pellet Fuel }}$ & KY & Hardwood & 55,000 \\
\hline Spearfish Pellet Co. LLC & $\mathrm{SD}$ & Softwood & 58,000 \\
\hline Allegheny Pellet Corporation & PA & Hardwood & 60,000 \\
\hline Hamer Pellet Fuel Elkins & WV & Hardwood & 60,000 \\
\hline North Idaho Energy Logs - Hauser & ID & Softwood & 60,000 \\
\hline Queston Wood Pellets & VT & Softwood & 60,000 \\
\hline Forest Energy Corp. & $\mathrm{AZ}$ & Softwood & 62,000 \\
\hline Marth Peshtigo Pellet Co. - Peshtigo & WI & Hardwood & 64,000 \\
\hline Marth Wood Shavings Supply & WI & Hardwood & 64,000 \\
\hline Northeast Wood Products LLC - Peebles & $\mathrm{OH}$ & Hardwood and Softwood & 65,000 \\
\hline Fiber By-Products - White Pigeon & MI & Hardwood & 65,000 \\
\hline Great Lakes Renewable Energy Inc. & WI & Hardwood and Softwood & 70,000 \\
\hline Deadwood Biofuels LLC & $\mathrm{SD}$ & Softwood & 71,000 \\
\hline American Wood Fibers - Marion & VA & Hardwood and Softwood & 75,000 \\
\hline Fiber Recovery Inc. & WI & Hardwood & 75,000 \\
\hline Nature's Earth Pellets NC LLC - Reform & $\mathrm{AL}$ & Softwood & 75,000 \\
\hline Schuyler Manufacturing Facility & NY & Hardwood and Softwood & 77,000 \\
\hline Equustock - Chester & VA & Hardwood and Softwood & 80,000 \\
\hline
\end{tabular}

Project information in accordance with DOE Contract No. DE-AC07-05ID1451 Do Not Further Disclose or Disseminate. 


\begin{tabular}{|c|c|c|c|}
\hline Fiber Energy Products AR LLC & AR & Hardwood & 80,000 \\
\hline Lignetics of Idaho Inc & ID & Softwood & 80,000 \\
\hline Corinth Wood Pellets LLC & $\mathrm{ME}$ & Hardwood and Softwood & 85,000 \\
\hline Jaffrey Manufacturing Facility & $\mathrm{NH}$ & Hardwood and Softwood & 85,000 \\
\hline Deposit Manufacturing Facility & NY & Hardwood and Softwood & 88,000 \\
\hline Varn Wood Pellets & GA & Softwood & 88,000 \\
\hline$\underline{\text { Lignetics of Maine Inc }}$ & $\mathrm{ME}$ & Hardwood & 90,000 \\
\hline Indeck Energy Ladysmith Biofuel Center LLC & WI & Hardwood and Softwood & 90,000 \\
\hline Lignetics of Virginia Inc. & VA & Hardwood & 90,000 \\
\hline Confluence Energy-Kremmling & $\mathrm{CO}$ & Softwood & 90,000 \\
\hline Wood Fibers Inc. & WI & & 90,000 \\
\hline Nature's Earth Pellets NC LLC - Laurinburg & NC & Hardwood and Softwood & 100,000 \\
\hline Dry Creek Products & NY & Hardwood & 100,000 \\
\hline Maine Woods Pellet Company & $\mathrm{ME}$ & Hardwood and Softwood & 105,000 \\
\hline Lee Energy Solutions & $\mathrm{AL}$ & Hardwood & 110,000 \\
\hline Bayou Wood Pellets & LA & Hardwood and Softwood & 120,000 \\
\hline Curran Renewable Energy LLC & NY & Hardwood and Softwood & 120,000 \\
\hline Energex America Inc. & $\mathrm{PA}$ & Hardwood & 120,000 \\
\hline Greenwood Fuels & WI & Paper Waste & 120,000 \\
\hline Mallard Creek Inc. & $\mathrm{CA}$ & Softwood & 120,000 \\
\hline Confluence Energy-Walden & $\mathrm{CO}$ & Softwood & 120,000 \\
\hline Enviva Pellets Amory & MS & Hardwood and Softwood & 121,000 \\
\hline Enviva Pellets Wiggins & MS & Hardwood and Softwood & 121,000 \\
\hline Lignetics of West Virginia Inc. & WV & Hardwood & 125,000 \\
\hline Bear Mountain Forest Products- Brownsville & OR & Softwood & 125,000 \\
\hline$\underline{\text { Trae Fuels Ltd - Pellet Plant }}$ & VA & Hardwood and Softwood & 130,000 \\
\hline Northeast Wood Products LLC - Ligonier & IN & & 130,000 \\
\hline Ozark Hardwood Pellets & $\mathrm{MO}$ & Hardwood & 140,000 \\
\hline Nahunta Pellets & GA & Softwood & 150,000 \\
\hline Telfair Forest Products LLC & GA & Softwood & 150,000 \\
\hline Solvay Biomass Energy LLC & MS & Hardwood and Softwood & 240,000 \\
\hline Appling County Pellets LLC & GA & Hardwood and Softwood & 243,000 \\
\hline Zilkha Biomass - Selma & $\mathrm{AL}$ & Hardwood and Softwood & 303,000 \\
\hline Westervelt Renewable Energy LLC & $\mathrm{AL}$ & Softwood & 309,000 \\
\hline Enviva Pellets Ahoskie & NC & Hardwood and Softwood & 449,000 \\
\hline Morehouse BioEnergy & GA & Woody Biomass & 496,000 \\
\hline Amite BioEnergy & MS & Hardwood and Softwood & 500,000 \\
\hline Blue Sky Biomass Georgia LLC & GA & Woody Biomass & 540,000 \\
\hline Enviva Pellets Northampton LLC & NC & Hardwood and Softwood & 550,000 \\
\hline
\end{tabular}

Project information in accordance with DOE Contract No. DE-AC07-05ID1451 Do Not Further Disclose or Disseminate. 


\section{Milestone Completion Report}

\begin{tabular}{|l|l|l|r|}
\hline Enviva Pellets Southampton LLC & VA & Hardwood and Softwood & 550,000 \\
\hline Enviva Pellets Hamlet & NC & Woody Biomass & 550,000 \\
\hline German Pellets Texas & TX & Hardwood and Softwood & 551,155 \\
\hline German Pellets Louisiana LLC & LA & Softwood & 578,000 \\
\hline Enviva Pellets Cottondale LLC & FL & Softwood & 660,000 \\
\hline Hazlehurst Wood Pellets LLC & GA & Softwood & 700,000 \\
\hline Georgia Biomass & GA & Softwood & 825,000 \\
\hline SUM Operational Capacity (tons per year) & & $\mathbf{1 4 , 4 2 5 , 5 2 0}$ \\
\hline
\end{tabular}

